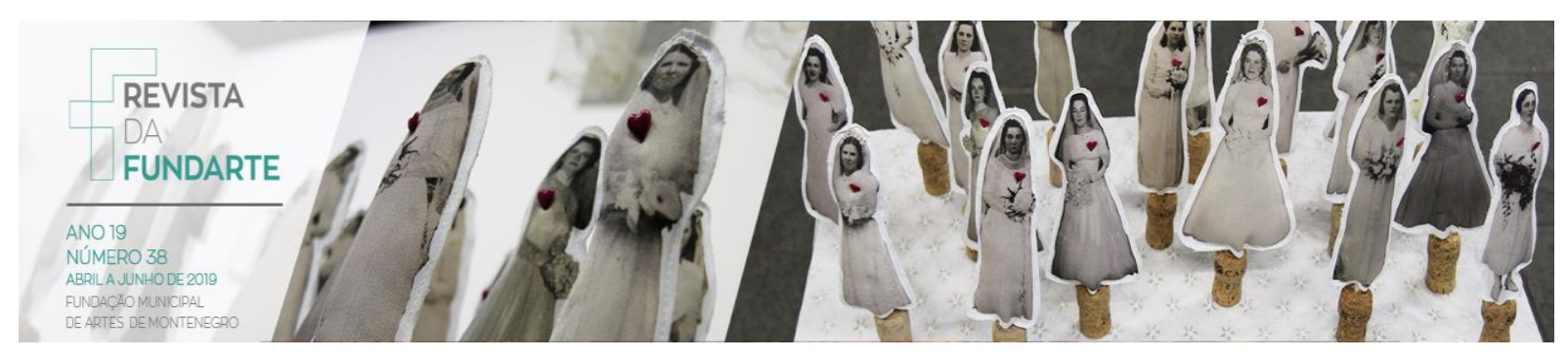

\title{
FORMAÇÃO DE PROFESSORES NO CURSO DE LICENCIATURA EM MÚSICA: UMA EXPERIÊNCIA COM A PRÁTICA INSTRUMENTAL E COMPOSICIONAL COM A FLAUTA-DOCE'
}

\author{
Maria Cecilia de Araujo Rodrigues Torres ${ }^{1}$ \\ Anete Susana Weichselbaum ${ }^{2}$
}

\begin{abstract}
Resumo: Esse texto apresenta um relato de experiência referente ao desenvolvimento da prática instrumental e composicional realizado com três turmas da disciplina de flauta doce em um curso de Licenciatura em Música ao longo de dois semestres. As variações foram analisadas por critérios musicais e de execução. Como aporte teórico, são considerados os conhecimentos e habilidades musicais (BALLANTYNE, 2005, 2006), os conhecimentos do conteúdo da matéria (SHULMAN, 1986) e conhecimentos e habilidades do conteúdo (WEICHSELBAUM, 2013), neste caso, a disciplina flauta doce. Ao finalizarmos essas reflexões, ressaltamos o quanto essa atividade foi instigante e desafiadora, não só para os nossos alunos, mas também para nós professoras, no sentido de ampliarmos os nossos fazeres musicais em sala de aula e trabalharmos com diferentes propostas para a flauta doce no contexto do Ensino Superior, inclusive com o propósito de exercitarmos a escrita e análise de partituras e textos em conjunto.
\end{abstract}

Palavras-chave: licenciatura em música, prática instrumental, flauta-doce

\section{TRAINING OF TEACHERS IN THE COURSE OF DEGREE IN MUSIC: AN EXPERIMENT WITH INSTRUMENTAL AND COMPOSITIONAL PRACTICE WITH THE SWEET FLUTE}

Abstract: This text presents a report of experience related to developing instrumental and compositional practice done with three classes of a course of recorder in a Music Graduation Course in two semesters. The variations were analyzed according to music criteria and of performance. As a theoretical support it was considered music knowledge and skills (BALLANTYNE, 2005, 2006), subject

\begin{abstract}
${ }^{1}$ Mestre em Educação pela Pontifícia Universidade Católica do Rio Grande do Sul (1995) e doutora em Educação pela Universidade Federal do Rio Grande do Sul (2003). Pesquisadora do grupo Cotidiano e Educação Musical do PPGMúsica-UFRGS (CNPq), sob a coordenação da profa. Dra. Jusamara Souza e pesquisadora convidada do Grupo de Pesquisa NarraMus - Auto-Narrativas de Práticas Musicais (UFSM). Professora do Curso de Licenciatura em Música do Centro Universitário Metodista IPA desde 2008. Foi coordenadora do Subprojeto Música do PIBID-IPA-CAPES (2012 a 2017) e coordenadora Institucional do PIBID/CAPES/IPA de julho de 2017 a fevereiro de 2018.

2 É formada em Licenciatura em Música pela EMBAP (atual Campus de Curitiba I da UNESPAR), mestre em Música pela Universidade Federal do Estado do Rio de Janeiro - UNIRIO (2003) e doutora em Música - Educação Musical pela Universidade Federal do Rio Grande do Sul - UFRGS (2013). Professora adjunta na UNESPAR Campus de Curitiba I - Embap, leciona atualmente no Curso de Licenciatura em Música, é professora colaboradora no Programa de Pós-Graduação em Música, e, desde 2013, lidera o Grupo de Pesquisas EPEM - Epistemologias e Práticas em Educação Musical. É coautora do livro Sonoridades Brasileiras: método para flauta doce soprano.
\end{abstract}

TORRES, Maria Cecilia de Araujo Rodrigues; WEICHSELBAUM, Anete Susana. Formação de professores no curso de licenciatura em música: Uma experiência com a prática instrumental e composicional com a flauta-doce. Revista da FUNDARTE, Montenegro, p.164-189, ano 19, no 38, abril/junho de 2019.

Disponível em: http://.seer.fundarte.rs.gov.br/index.php/RevistadaFundarte/index> 28 de junho de 2019 


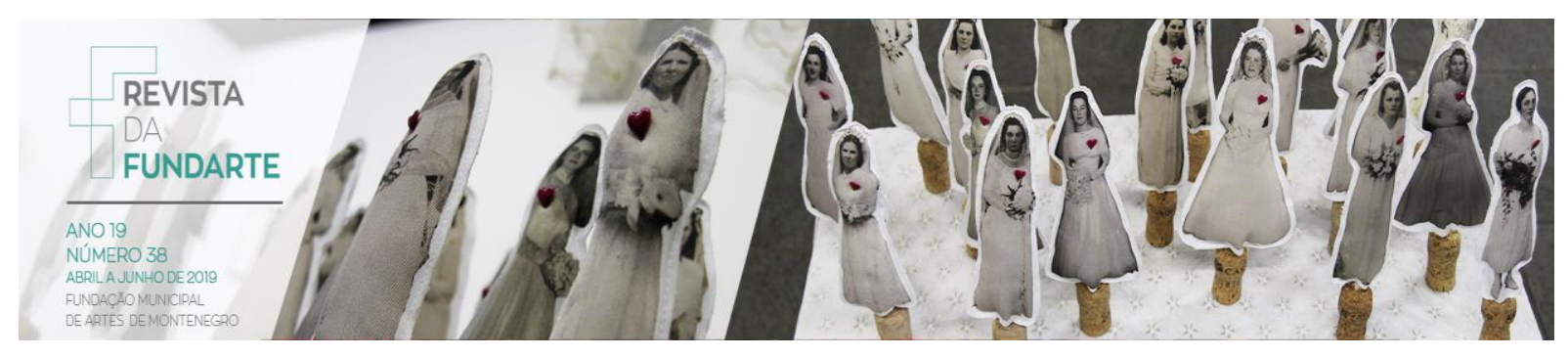

matter content knowledge, and knowledge and skills of the content (WEICHSELBAUM, 2013), in this case the discipline of recorder. This activity was challenging and instigating not only for the students but also for the teachers, in the sense of increasing of the music knowledge in the classroom, as well as to practice different proposals for the recorder in the context of an University course, including with the proposal of exercising together the writing, and analyzing of musical scores and texts.

Keywords: music graduation course, instrumental practice, recorder

\section{Problemática}

Um dos desafios para a formação de professores nos cursos de licenciatura em música é responder às questões: que conhecimentos e habilidades são pertinentes à formação musical do licenciando em música? Ou ainda, que conhecimentos e habilidades musicais a prática instrumental deve promover? Segundo Conway e Hodgmam (2009), as habilidades se referem à maneira como os estudantes realizam as ações como cantar, tocar instrumentos, improvisar, interagir musicalmente com outros e inclui os comportamentos e a percepção aural, considerando-se um determinado contexto musical.

Investigando como os docentes em formação aprendem a ensinar, e focalizando a compreensão e transmissão de seus conhecimentos, Shulman (1986) definiu, no campo da educação, que o conhecimento do conteúdo pode ser subdividido em três categorias: o conhecimento do conteúdo da matériaii (subject matter content knowledge), ou seja, o que ensinar, o conhecimento pedagógico do conteúdo (Pedagogical Content Knowledge - PCK) iii, ou seja, como ensinar e o conhecimento curricular (curricular knowledge) que se refere à compreensão dos programas de ensino e dos materiais que subsidiam as disciplinas.

No campo da educação musical, Ballantyne $(2005 ; 2006)$ avaliou programas de formação de professores de música na Austrália quando seus egressos encontravam-se lecionando nos três primeiros anos da profissão e, considerando os conhecimentos e habilidades necessárias à formação do licenciando, propôs quatro categorias derivadas da categorização estabelecida inicialmente por Shulman.

TORRES, Maria Cecilia de Araujo Rodrigues; WEICHSELBAUM, Anete Susana. Formação de professores no curso de licenciatura em música: Uma experiência com a prática instrumental e composicional com a flauta-doce. Revista da FUNDARTE, Montenegro, p.164-189, ano 19, ㄲo 38 , abril/junho de 2019.

Disponível em: http://.seer.fundarte.rs.gov.br/index.php/RevistadaFundarte/index> 28 de junho de 2019 


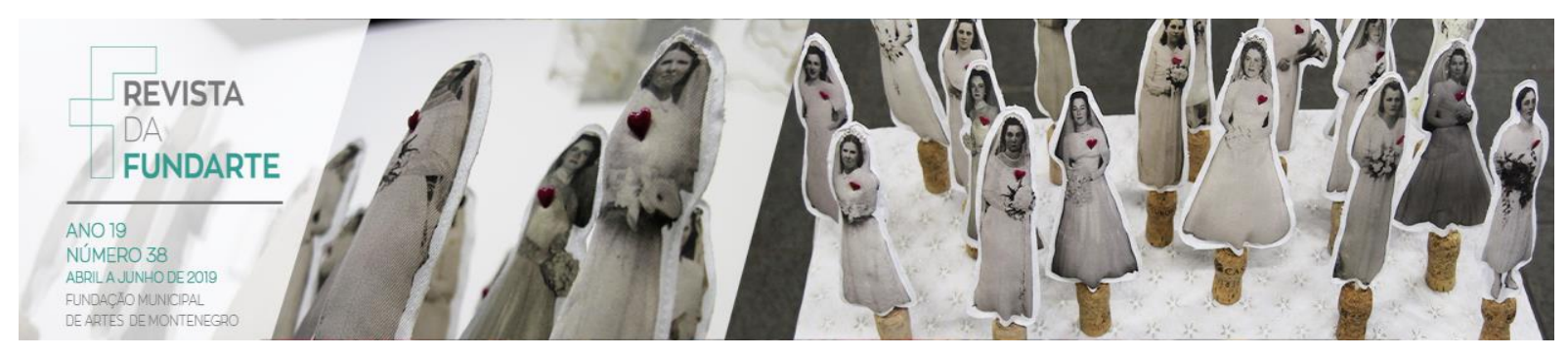

Levando em conta a natureza da formação em música, Ballantyne $(2005,2006)$ acrescentou aos conhecimentos o termo habilidades (skill), resultando nas seguintes categorias: conhecimentos e habilidades musicais, conhecimentos e habilidades pedagógicos do conteúdo, conhecimentos e habilidades profissionais e conhecimentos e habilidades gerais da educação.

Para Ballantyne (2005), o conhecimento e a habilidade musical engloba todos aqueles desenvolvidos em disciplinas incluídas nos currículos de graduação em música, tais como Harmonia, Estruturação Musical, Análise, Percepção e Contraponto. Para a autora: "[e]ssa categoria inclui as áreas relativas às habilidades da performance, habilidades da regência, habilidades de percepção aural, habilidades composicionais e conhecimentos de história da música" (BALLANTYNE, 2006, p. 45)

A categoria conhecimentos e habilidades gerais da educação contempla "o conhecimento dos aprendizes e suas características, [...], a habilidade de organizar - ambiente de aprendizagem e a capacidade de utilizar várias estratégias instrucionais" (BALLANTYNE, 2006, p. 44)v . Os conhecimentos e habilidades pedagógicos do conteúdo referem-se, por exemplo, ao "conhecimento de técnicas de ensino de música, [...], avaliação das habilidades musicais dos alunos em vários aspectos da música e a explanação e demonstração dos conceitos musicais ${ }^{\text {vi }}$ (BALLANTYNE, 2006, p. 41). Na categoria de conhecimentos e habilidades profissionais, enquadram-se atividades como organização de concertos e seleção de alunos para formar as orquestras na escola (BALLANTYNE, 2005, 2006).

O presente trabalho consiste em um relato de experiência que aborda quais são os conhecimentos e as habilidades musicais e instrumentais requeridos de licenciandos no estudo e prática de flauta doce, apoiado nos estudos de Shulman (1986) e Ballantyne (2005; 2006). Posteriormente, Weichselbaum (2013), que analisou conhecimentos e habilidades desenvolvidos por licenciandos no estudo de

TORRES, Maria Cecilia de Araujo Rodrigues; WEICHSELBAUM, Anete Susana. Formação de professores no curso de licenciatura em música: Uma experiência com a prática instrumental e composicional com a flauta-doce. Revista da FUNDARTE, Montenegro, p.164-189, ano 19, ํㅜ 38, abril/junho de 2019.

Disponível em: http://.seer.fundarte.rs.gov.br/index.php/RevistadaFundarte/index> 28 de junho de 2019 


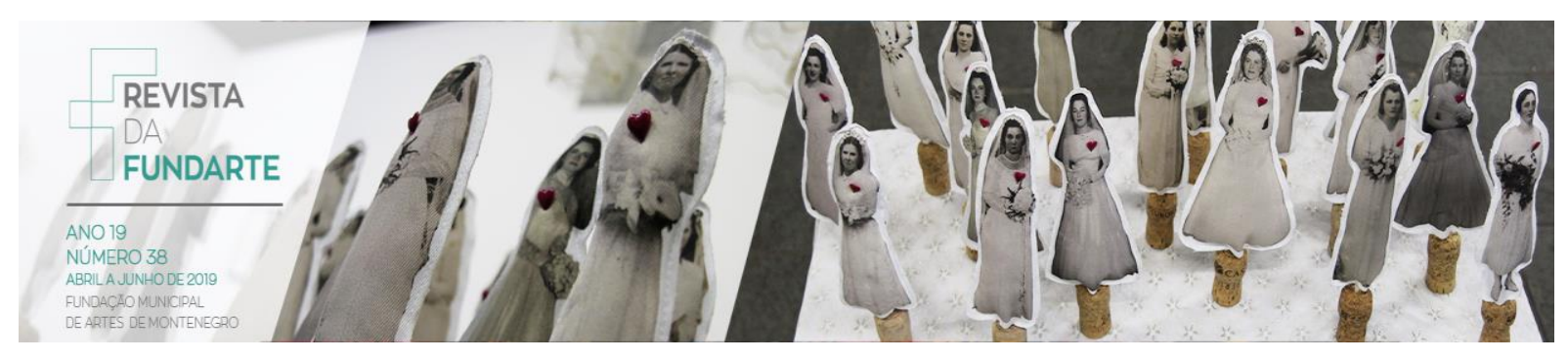

flauta doce e no desenvolvimento de propostas pedagógicas para o instrumento em uma mesma disciplina, acrescentou o termo habilidade à categoria conhecimento do conteúdo inicialmente proposta por Shulman (1986), por considerar que uma disciplina com foco no ensino instrumental demanda tanto conhecimentos quanto habilidades necessárias à compreensão e à performance.

O artigo apresenta, inicialmente, o contexto no qual a experiência é realizada, tomando como exemplo a disciplina intitulada Flauta-doce no contexto escolar e as atividades nela desenvolvidas. A partir de uma atividade de composição - execução de um tema musical e variações em torno desse tema - são discutidos conhecimentos e habilidades musicais construídos na prática musical coletiva. A análise das composições contempla os aspectos musicais e de execução, examinando-as de acordo com as categorias propostas, que são: conhecimentos e habilidades musicais bem como conhecimento (e habilidade) do conteúdo.

\section{A experiência e como ela pode ser interpretada}

A seguir, relatamos uma experiência realizada no contexto de uma disciplina específica de flauta doce em um curso de licenciatura em música que é ofertada no segundo semestre.

\subsection{0 contexto da experiência: curso superior}

Muitos cursos de licenciatura em música oferecem e requerem dos graduandos o estudo de instrumento(s) durante o curso, tais como violão, piano, teclado, flauta doce, ukulelê, percussão, instrumentos de cordas friccionadas, entre outros, além do canto. Geralmente o estudo desses instrumentos aprimora sua formação músico-instrumental, bem como objetiva capacitá-los a desenvolver atividades pedagógicas práticas que envolvam o instrumento.

TORRES, Maria Cecilia de Araujo Rodrigues; WEICHSELBAUM, Anete Susana. Formação de professores no curso de licenciatura em música: Uma experiência com a prática instrumental e composicional com a flauta-doce. Revista da FUNDARTE, Montenegro, p.164-189, ano 19, № 38, abril/junho de 2019.

Disponível em: http://.seer.fundarte.rs.gov.br/index.php/RevistadaFundarte/index> 28 de junho de 2019 


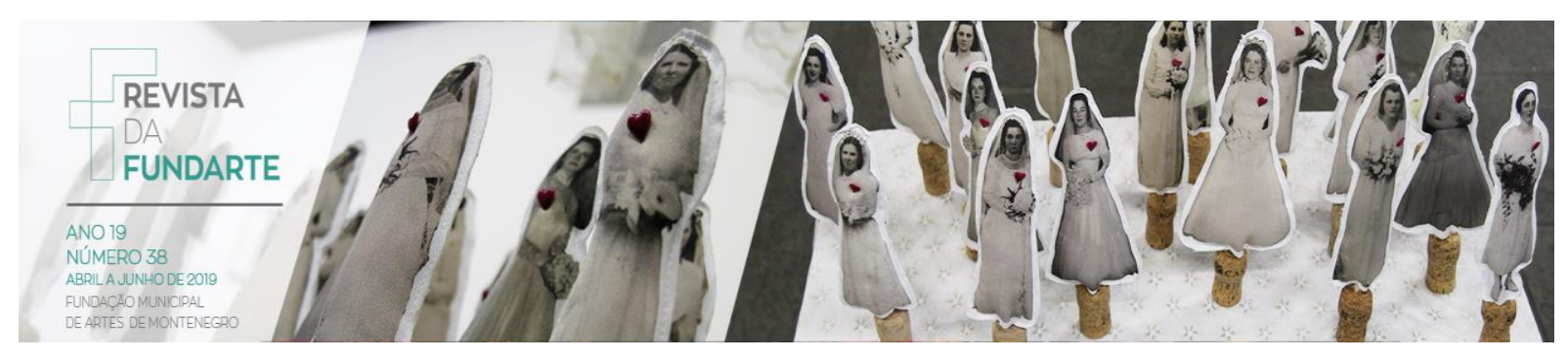

Destacamos que este relato refere-se a um Curso em que não há prova específica de música para o ingresso, tendo o vestibular geral, o que torna as turmas ecléticas em termos de conhecimentos, habilidades musicais, estilos e experiências.

Em relação ao ensino de flauta doce, a proposta de se trabalhar em um curso de Licenciatura em Música com a formação de docentes, apoia-se nas ideias de Weiland, Sasse e Weichselbaum (2009), ao pontuarem: "[n]ossa preocupação é que a qualidade deste ensino seja fundada numa prática consciente de possibilidades do instrumento. Pensamos que a flauta doce não deve servir apenas como um recurso auxiliar na musicalização, mas deve proporcionar uma base sólida para 0 aprendizado musical através deste instrumento" (WEILAND; SASSE; WEICHSELBAUM, 2009, p.8).

\subsection{A disciplina: fundamentos, objetivos, repertório e atividades}

A disciplina Flauta doce no contexto escolar é ofertada no segundo semestre do Curso de Licenciatura em Música do Centro Universitário Metodista IPA, os estudantes trabalham com a flauta doce soprano durante as disciplinas Flauta doce, que é oferecida no $1^{\circ}$ semestre e Flauta doce no contexto escolar que acontece no $2^{2}$ semestre. Durante o segundo semestre, os alunos têm acesso a uma bibliografia básica de artigos e pesquisas de educadores musicais que trabalham com a flauta doce em espaços da escola básica e no ensino superior, com o propósito de articular as leituras feitas com discussão, escrita de resenhas e organização de planejamentos de aulas com o uso da flauta doce. Estas leituras e discussões em sala de aula oportunizaram reflexões e estranhamentos sobre o papel da prática da flauta doce na aula de música tanto no espaço da escola de educação básica quanto nos currículos dos Cursos de Licenciatura em Música e também como um

TORRES, Maria Cecilia de Araujo Rodrigues; WEICHSELBAUM, Anete Susana. Formação de professores no curso de licenciatura em música: Uma experiência com a prática instrumental e composicional com a flauta-doce. Revista da FUNDARTE, Montenegro, p.164-189, ano 19, ํㅜ 38, abril/junho de 2019.

Disponível em: http://.seer.fundarte.rs.gov.br/index.php/RevistadaFundarte/index> 28 de junho de 2019 


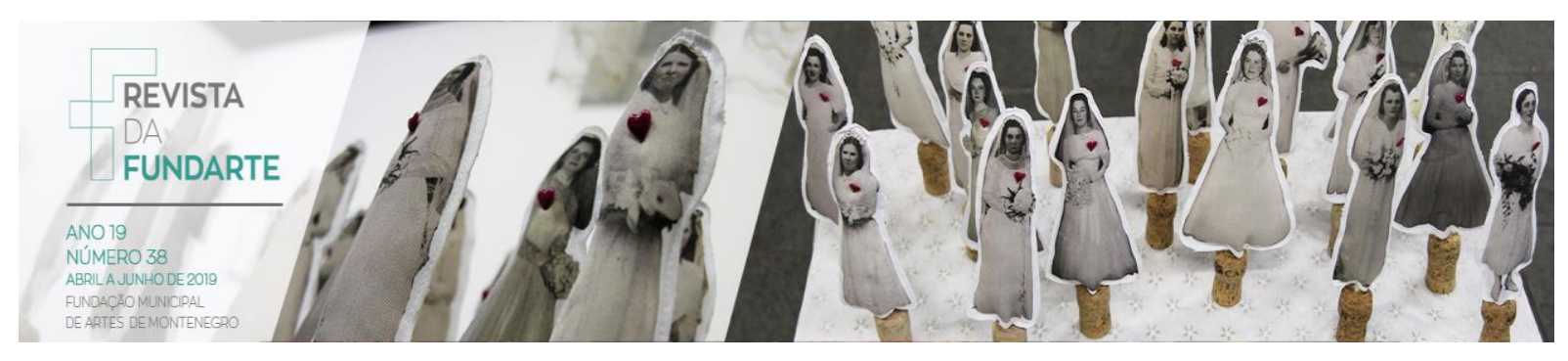

instrumento que faz parte dos planejamentos de aulas de muitos estagiários de música no momento de suas práticas na escola.

Desta forma, dentre os objetivos das disciplinas estão o conhecimento do instrumento nos seus aspectos físicos, estilísticos, o trabalho com questões de respiração, digitação, articulação e a fluência na execução da flauta doce, assim como também constam objetivos que requerem dos estudantes a seleção, organização de repertórios, realização de arranjos e propostas musicais para a sala de aula da escola de educação básica a partir do uso da flauta doce.

Em relação à proposta da flauta doce nos dois semestres deste Curso de Licenciatura em Música, considerando que nas turmas a grande maioria dos licenciandos tem o seu primeiro contato com a flauta doce durante o curso, sem conhecimentos prévios da prática do instrumento, 0 trabalho prioriza abordar também questões relacionadas com a prática instrumental coletiva e com propostas metodológicas para o educador musical trabalhar no âmbito da Escola de Educação Básica.

A partir da literatura consultada, evidencia-se que é necessário desenvolver conhecimentos e habilidades do conteúdo da matéria (SHULMAN, 1986; WEICHSELBAUM, 2013) para que os licenciandos os adquiram e os aprimorem. No caso da presente disciplina, compete ao professor desenvolver conhecimentos e habilidades necessárias para o estudo e prática da flauta doce. Outro aspecto relevante a identificar está relacionado aos conhecimentos e habilidades musicais (BALLANTYNE, 2005; 2006) que os licenciandos adquirem em outras disciplinas, sob orientação de outros professores, o que influi na compreensão e prática instrumental.

No contexto das turmas que participaram desta atividade, buscou-se trabalhar na perspectiva de um aprofundamento de aspectos da técnica do instrumento, com a inserção da flauta doce tenor, a ampliação de repertório com estilos musicais

TORRES, Maria Cecilia de Araujo Rodrigues; WEICHSELBAUM, Anete Susana. Formação de professores no curso de licenciatura em música: Uma experiência com a prática instrumental e composicional com a flauta-doce. Revista da FUNDARTE, Montenegro, p.164-189, ano 19, ㄲo 38 , abril/junho de 2019.

Disponível em: http://.seer.fundarte.rs.gov.br/index.php/RevistadaFundarte/index> 28 de junho de 2019 


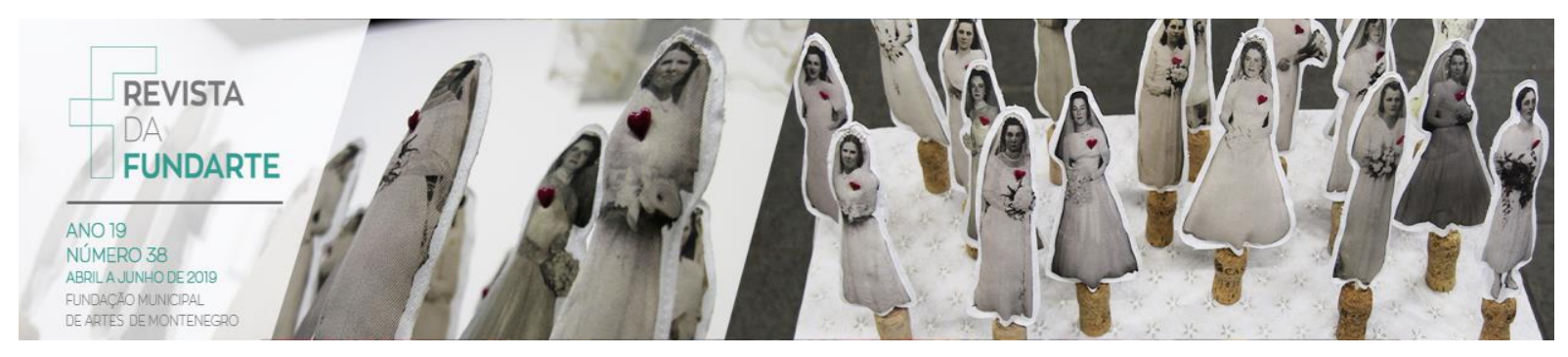

distintos com peças como Peixinhos do Mar (arranjo de Viviane Beineke), Tourdion (Pierre Attaingnant), Jennie Mamma (folclore Caribenho e arranjo de Viviane Beineke) e Carinhoso (Pixinguinha e arranjo para flauta doce de Geraldo Telles do Amaral).

\subsection{A atividade: Variações para um Tema: criações na aula de flauta doce}

Muitos professores e educadores musicais advogam que licenciandos devam ter a oportunidade de compor e improvisar pequenos trechos musicais e executá-los durante sua formação (LIRA, 1984; TRINDADE, 2007; FREIXEDAS, 2015). Lira (1984), uma das pioneiras a advogar a favor de um ensino criativo, afirma que a formação de um licenciando deveria contemplar aspectos de improvisação, sugerindo a realização de perguntas-e-respostas melódicas, bem com a realização de arranjos para grupos instrumentais de flauta doce e dos instrumentos que os graduandos já tocam.

Mais recentemente, Freixedas (2015) analisou práticas de ensino de flauta doce voltadas a crianças e jovens alunos de flauta doce e licenciandos, as quais priorizassem um fazer musical inicial criativo e voltado para a execução de repertório dos séculos XX e XXI. Quanto aos aspectos criativos relacionados à improvisação, a autora pontua que

[d]esde os primeiros sons explorados e as primeiras posições aprendidas, é possível improvisar, criar variações rítmicas, bem como articulações e pequenas frases melódicas, bem como articulações e pequenas frases melódicas. Com um pouco mais de notas, é possível improvisar sobre escalas pentatônicas, com as notas de uma melodia que esteja sendo trabalhada, com uma progressão harmônica determinada, podendo, ainda, somar a estas notas as novas técnicas e sonoridades conhecidas, em improvisações mais dirigidas, idiomáticas ou mais livres, de diferentes modos (FREIXEDAS, 2015, p. 89).

TORRES, Maria Cecilia de Araujo Rodrigues; WEICHSELBAUM, Anete Susana. Formação de professores no curso de licenciatura em música: Uma experiência com a prática instrumental e composicional com a flauta-doce. Revista da FUNDARTE, Montenegro, p.164-189, ano 19, ㄲo 38, abril/junho de 2019.

Disponível em: http://.seer.fundarte.rs.gov.br/index.php/RevistadaFundarte/index> 28 de junho de 2019 


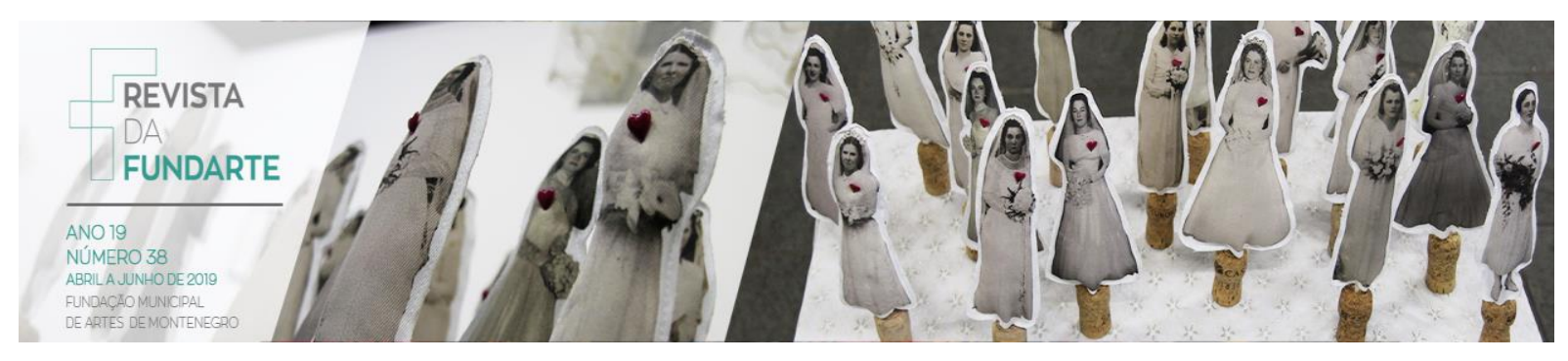

Partindo dessas premissas, propusemos um trabalho de criação/composição de variações a partir da execução do "Dueto: Tema e variações" para flauta doce soprano. O trabalho foi realizado por três turmas da disciplina de Flauta doce no contexto escolar, nos semestres de 2014/2 e 2015 do Curso de Licenciatura em Música do Centro Universitário Metodista IPA. A melodia que originou esta proposta de criação de variações encontra-se no Método para flauta doce soprano intitulado Sonoridades Brasileiras, de autoria de Renate Weiland, Ângela Sasse e Anete Weichselbaum (2009, p. 66).

A proposta inicial foi de que os alunos tocassem a peça Dueto: Tema e variações, composta por um Tema e três variações, a duas vozes na flauta soprano, em sol maior. Os estudantes tiveram a oportunidade de tocar as duas vozes na flauta, em duplas e, depois, todas as variações ao mesmo tempo, com um colega tocando o tema ao piano.

O segundo passo da atividade foi pedir que criassem variações para este tema, que poderiam ser feitas individualmente, em duplas, trios, quartetos e quintetos, dependendo do tamanho da turma. Essa etapa da atividade consistiu na criação de uma variação e foi pedido aos licenciandos que mantivessem a extensão do trecho musical (oito compassos), a tonalidade, assim como o compasso binário da música apresentada no Método Sonoridades Brasileiras. Salienta-se que a própria tarefa se configura com estas restrições. Algumas duplas criaram sua variação a duas vozes, mas a grande maioria dos estudantes criou uma voz, identificando-a como uma nova variação.

A seguir, cada uma das duplas tocou a sua variação acompanhada pelos colegas que escolhiam uma voz qualquer do Tema ou de uma das três Variações e tocavam juntos. Algumas variações receberam títulos como: Variação $D$, Variação do Tema, Variação para flauta, Variação, Dueto variação $D$ e Variação Cecília. Este exercício de criação de uma variação está proposto no Método Sonoridades

TORRES, Maria Cecilia de Araujo Rodrigues; WEICHSELBAUM, Anete Susana. Formação de professores no curso de licenciatura em música: Uma experiência com a prática instrumental e composicional com a flauta-doce. Revista da FUNDARTE, Montenegro, p.164-189, ano 19, ㄲo 38 , abril/junho de 2019.

Disponível em: http://.seer.fundarte.rs.gov.br/index.php/RevistadaFundarte/index> 28 de junho de 2019 


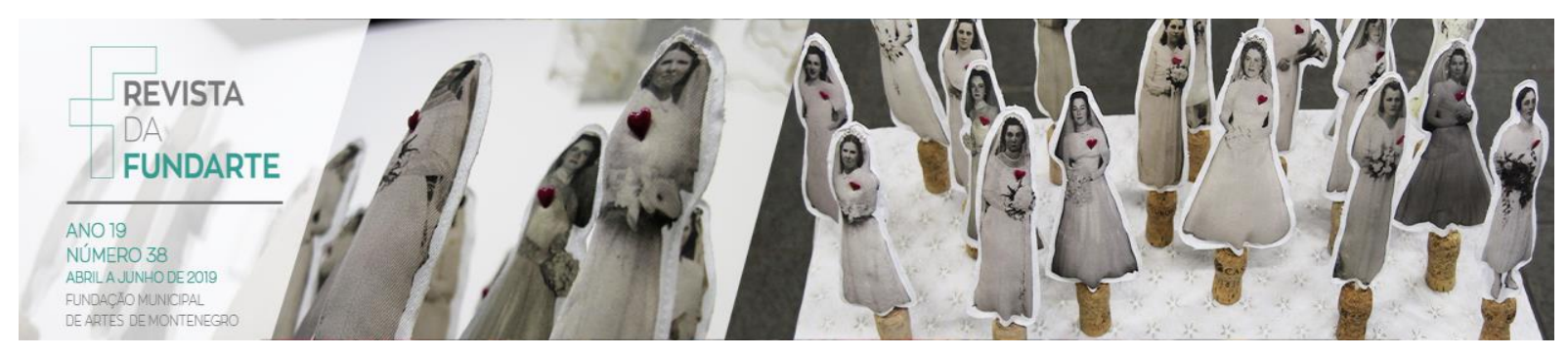

Brasileiras, logo abaixo das Variações A, B e C, com o seguinte enunciado: "Quais variações você consegue tocar? Você pode criar a sua": (WEILAND, SASSE, WEICHSELBAUM, 2009, p.66).

Ressaltamos também que ao final, os estudantes entregaram por escrito - na pauta - a composição das variações. Como material de análise, apresentamos dez das 20 variações realizadas pelo total de 62 alunos de três turmas desta disciplina, ao longo de dois semestres letivos.

\section{Resultados: Análise das variações apresentadas}

Os critérios apresentados para a análise das variações apresentadas foram examinados tanto por critérios musicais e de execução instrumental, quanto a partir de categorias propostas inicialmente por Shulman (1986) e Ballantyne $(2005,2006)$, que consideraram os conhecimentos e habilidades necessários para a docência. São eles: o conhecimento e habilidade musical (BALLANTYNE, 2005; 2006), bem como o conhecimento do conteúdo da matéria (SHULMAN, 1986), que é relativo à disciplina ou matéria em questão. Como já mencionado anteriormente, diante do entendimento de que o estudo do instrumento contempla a habilidade e não só seu conhecimento (BALLANTYNE, 2005; 2006), Weichselbaum (2013), em sua investigação, também adota as expressões conhecimento e habilidade do conteúdo para esta categoria inicialmente proposta por Shulman para se referir à compreensão dos licenciandos da matéria em si, que, neste caso, inclui tanto os conhecimentos da flauta doce, sua família, tessitura, como a habilidade de tocar o instrumento realizando corretamente aspectos como respiração, digitação e articulação.

A seguir apresentaremos dez das vinte variações criadas pelos estudantes ${ }^{\text {vii }}$ com o objetivo de analisarmos inicialmente: (a) aspectos musicais como

TORRES, Maria Cecilia de Araujo Rodrigues; WEICHSELBAUM, Anete Susana. Formação de professores no curso de licenciatura em música: Uma experiência com a prática instrumental e composicional com a flauta-doce. Revista da FUNDARTE, Montenegro, p.164-189, ano 19, ㄲo 38, abril/junho de 2019.

Disponível em: http://.seer.fundarte.rs.gov.br/index.php/RevistadaFundarte/index> 28 de junho de 2019 


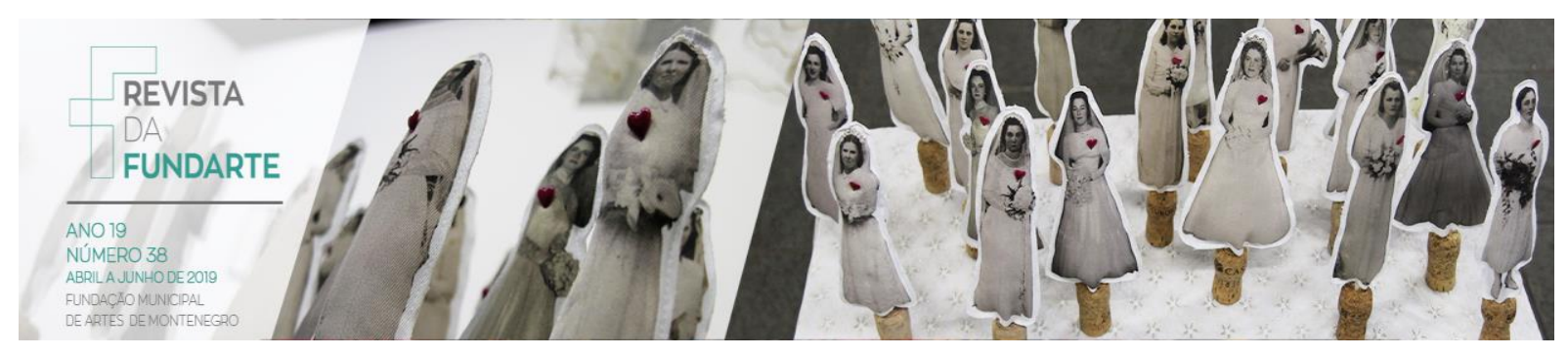

segmentação das frases musicais, unidade rítmica e/ou melódica, extensão utilizada e manutenção da harmonia do Tema (cifras); e (b) aspectos de execução.

Pelo fato de os estudantes cursarem o segundo semestre, e, como a tarefa proposta apresentava limitações, como já exposto, como tonalidade e extensão do trecho musical (oito compassos), consideraram-se apenas tais critérios, sem necessidade de maior aprofundamento de conhecimento musical nesta etapa do cursoviii. Os comentários gerais referem-se a todas as vinte variações compostas, porém, a fim de não sobrecarregar o presente artigo, os exemplos foram selecionados, tendo como critério a apresentação daqueles que tivessem elementos em comum, bem como os mais idiossincráticos.

Em relação à extensão (tessitura), a ordem dos exemplos apresentados está organizada, preferencialmente, de modo a apresentar sua gradativa ampliação, desde intervalos contidos no âmbito de uma quinta, sexta até a décima. Os estudantes utilizaram com mais frequência a extensão de oitavai ${ }^{i x}$, como no Tema apresentado ( Ré $^{3}$ a Ré ${ }^{4}$ ).

Os demais aspectos - segmentação das frases, unidade rítmico-melódica e manutenção da harmonia - mantém relação com conhecimentos e habilidades (BALLANTYNE, 2005; 2006) que são estudados ao longo de um curso de graduação em música e não são abordados exclusivamente na disciplina em questão. Em relação à segmentação das frases musicais, muitos estudantes compuseram duas frases (antecedente e consequente) bem delimitadas e simétricas, com as apresentadas nos quatro primeiros exemplos (Figura 1 até Figura 4). O Dueto: Tema e variações é estruturado dessa forma.

A Figura 1 apresenta uma variação muito semelhante ao Tema original da primeira voz, constituída por duas frases equidistantes, sendo a segunda semifrase igual à parte final do Tema fornecido. Ela apresenta unidade rítmico-melódica ao utilizar sequências formadas por graus conjuntos e pausas (motivo a e a'), emprega

TORRES, Maria Cecilia de Araujo Rodrigues; WEICHSELBAUM, Anete Susana. Formação de professores no curso de licenciatura em música: Uma experiência com a prática instrumental e composicional com a flauta-doce. Revista da FUNDARTE, Montenegro, p.164-189, ano 19, № 38, abril/junho de 2019.

Disponível em: http://.seer.fundarte.rs.gov.br/index.php/RevistadaFundarte/index> 28 de junho de 2019 


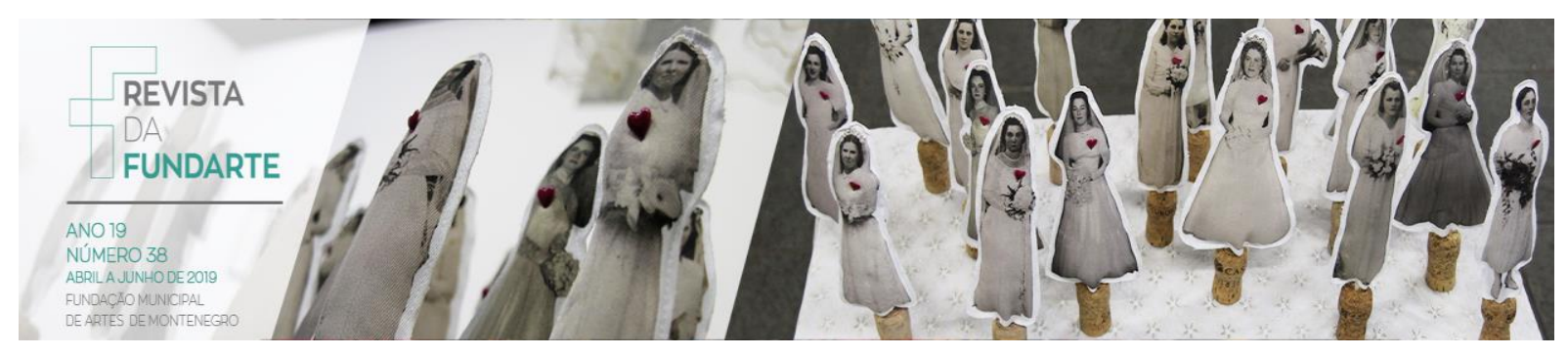

a extensão de uma quinta em ambas as frases e apresenta coerência harmônica com o Tema.

Figura 1 - Variação semelhante ao Tema do Dueto

H., H., M., R., J. e T.

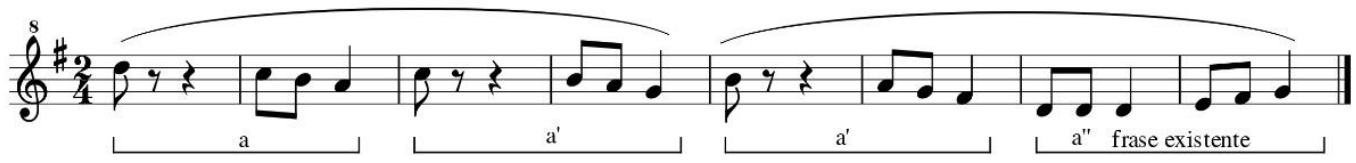

As próximas duas variações apresentam frases bem delimitadas, formadas também por semifrases ${ }^{x}$ com dois compassos cada, como no Tema proposto. Em tais exemplos (Figura 2 e 3 ) aparecem sequências originadas a partir dos dois primeiros compassos. Na Variação 2 (Figura 2) os contornos melódicos se assemelham até o final, enquanto que na Variação 3 (Figura 3), iniciada por motivos descendentes, o último motivo termina em movimento ascendente.

Figura 2 - Variação com uso de sequências dentro da extensão de uma sexta

A., L., R. e T.

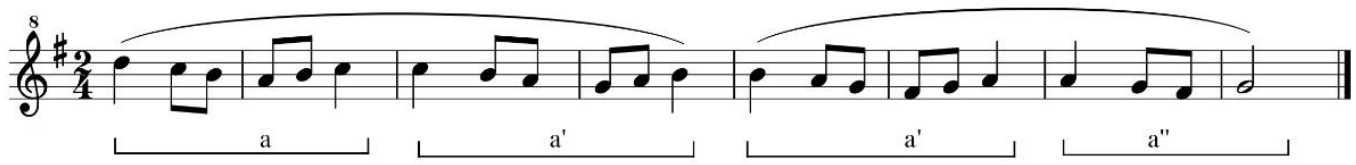

A Figura 2 apresenta duas sequências (a) transpostas a cada dois compassos, formadas por movimentos ascendentes e descendentes, sendo acrescida uma quarta sequência mais curta que termina na tônica.

A variação da Figura 3 foi composta por três sequências que utilizam, a cada dois compassos, ritmos sincopados e terminam com graus conjuntos. Ela apresenta grande semelhança rítmica em relação às duas frases, sendo apenas o terceiro e

TORRES, Maria Cecilia de Araujo Rodrigues; WEICHSELBAUM, Anete Susana. Formação de professores no curso de licenciatura em música: Uma experiência com a prática instrumental e composicional com a flauta-doce. Revista da FUNDARTE, Montenegro, p.164-189, ano 19, no 38, abril/junho de 2019.

Disponível em: http://.seer.fundarte.rs.gov.br/index.php/RevistadaFundarte/index> 28 de junho de 2019 


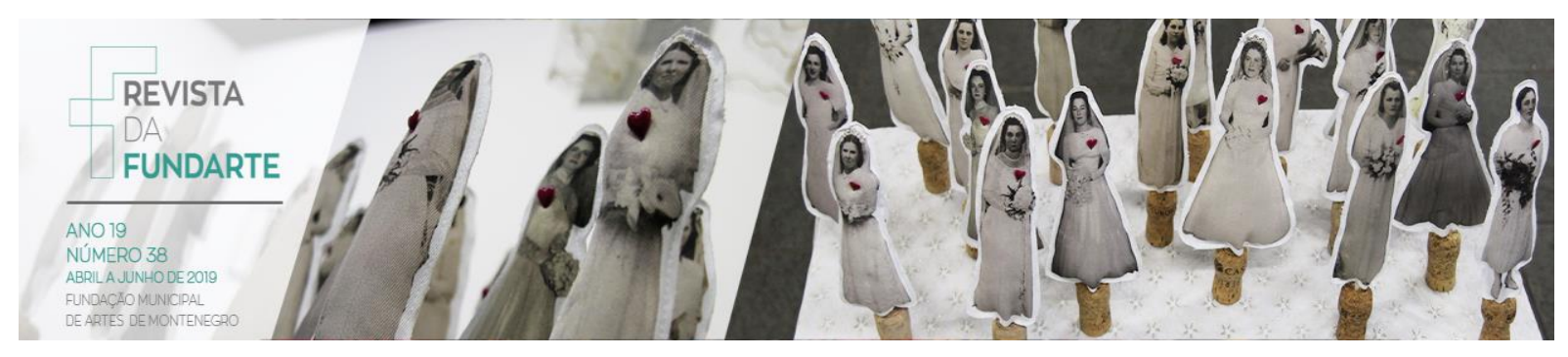

sétimo compasso formados por ritmos diferentes. As notas estruturais são as mesmas que as da primeira voz do Tema fornecido, utilizando notas de passagem (NP) indicadas sobre as respectivas notas.

Figura 3 - Variação com sequências, ritmos sincopados e contratempos

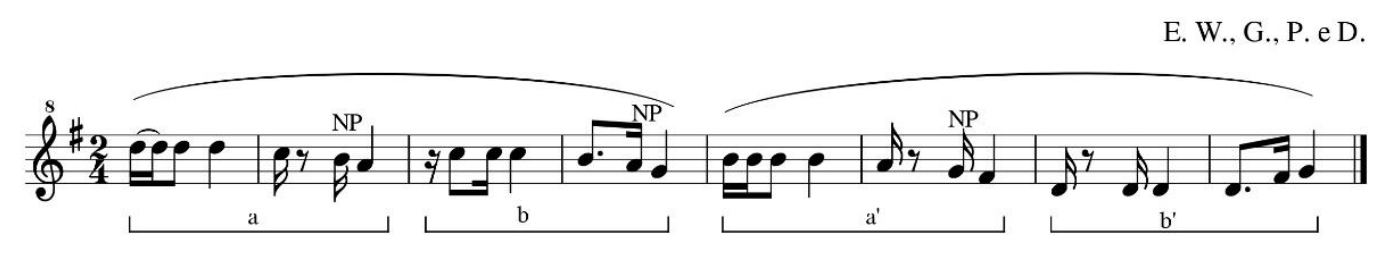

Os próximos três exemplos da Figura 4 apresentam uma divisão irregular das frases musicais e as últimas duas semifrases terminam com pausas. Utilizar pausas é um dos recursos utilizados para separar elementos fraseológicos (MATTOS, 2006). Contudo, observou-se que a divisão irregular das semifrases acarretou respirações diferentes na realização instrumental entre as vozes, pois a proposta da tarefa foi executar a variação composta junto com uma das vozes do Dueto original. A partir dessa constatação, sugere-se que professores analisem e ressaltem com os estudantes 0 aparecimento dessas situações e as implicações entre a segmentação realizada por eles na composição da variação e a respiração na execução na sua disciplina, considerando que aspectos estruturais do discurso musical são categorizados como conhecimentos musicais (BALLANTYNE, 2005, 2006) desenvolvidos em outras disciplinas.

A primeira composição da Figura 4 apresenta três semifrases. As duas primeiras são formadas pelo motivo $d$ formado pelos motivos $a$ e $b$, os quais são separados por pauta de semínima; o motivo $c$ é utilizado para finalizar a segunda semifrase e iniciar a terceira após um compasso de pausa. Observa-se a extensão contida dentro de uma sexta e a repetição do mesmo esquema de semicolcheias (compasso 2, 4 e 8).

TORRES, Maria Cecilia de Araujo Rodrigues; WEICHSELBAUM, Anete Susana. Formação de professores no curso de licenciatura em música: Uma experiência com a prática instrumental e composicional com a flauta-doce. Revista da FUNDARTE, Montenegro, p.164-189, ano 19, № 38, abril/junho de 2019.

Disponível em: http://.seer.fundarte.rs.gov.br/index.php/RevistadaFundarte/index> 28 de junho de 2019 


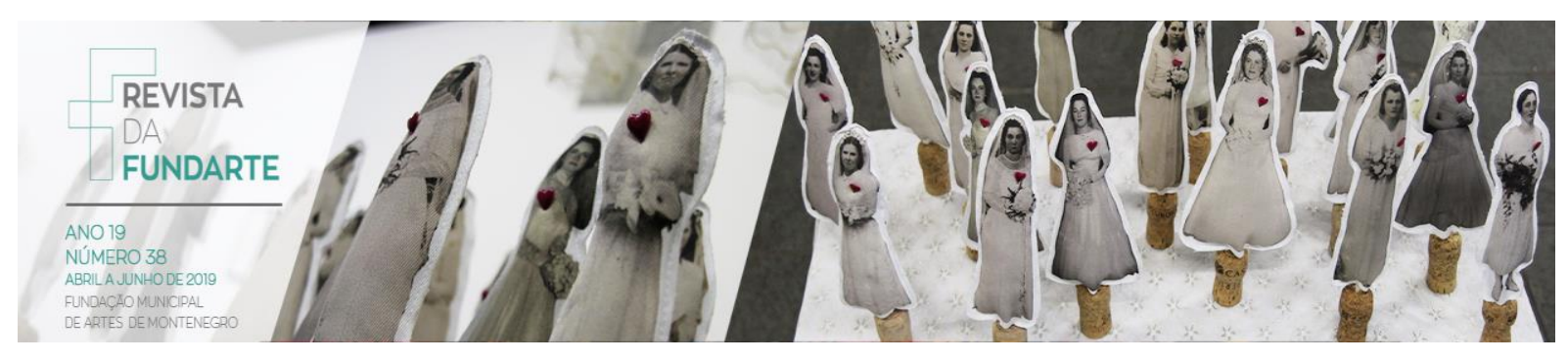

Figura 4 - Variações com frases irregulares

C., E., F., e J..

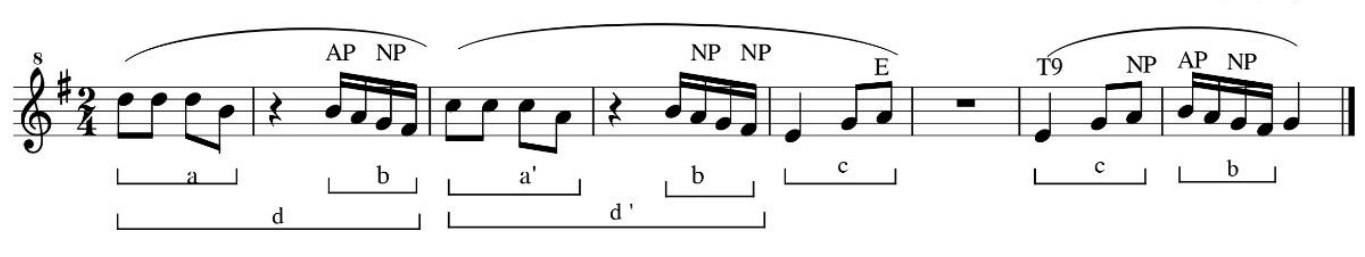

A. P., A., E., P., F. e E.

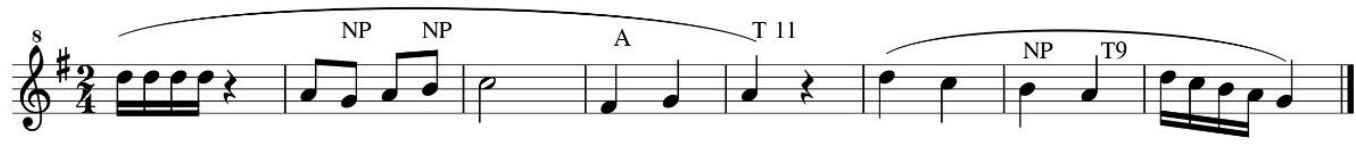

C. e A

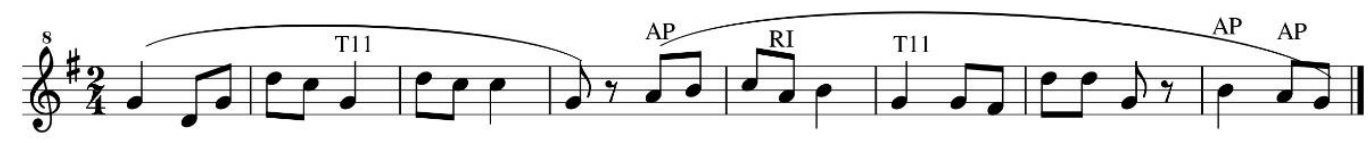

O segundo exemplo da Figura 4 utiliza frases irregulares com cinco e três compassos enquanto que o último exemplo emprega o início anacrústico na segunda semifrase (anacruse do compasso 4). A extensão dos trechos está contida dentro de uma oitava.

Em relação à extensão empregada, três variações de todas as 20 apresentadas incluíram posições estudadas em sala de aula da segunda oitava do instrumento $\left(\mathrm{Mi}^{4}\right.$ e Sol$\left.{ }^{4}\right)$, estruturadas em frases simétricas.

No primeiro exemplo da Figura 5, a duas vozes, cada voz mantém sua unidade rítmica, por exemplo, o início de cada frase da primeira voz começa em semicolcheias, as vozes fazem ritmos complementares, bem como, muitas vezes, movimentos melódicos em direções opostas ou enquanto uma nota se mantém, a outra se move em outra direção, resultando em ótimo efeito. Tal composição

TORRES, Maria Cecilia de Araujo Rodrigues; WEICHSELBAUM, Anete Susana. Formação de professores no curso de licenciatura em música: Uma experiência com a prática instrumental e composicional com a flauta-doce. Revista da FUNDARTE, Montenegro, p.164-189, ano 19, ㄲo 38, abril/junho de 2019.

Disponível em: http://.seer.fundarte.rs.gov.br/index.php/RevistadaFundarte/index> 28 de junho de 2019 


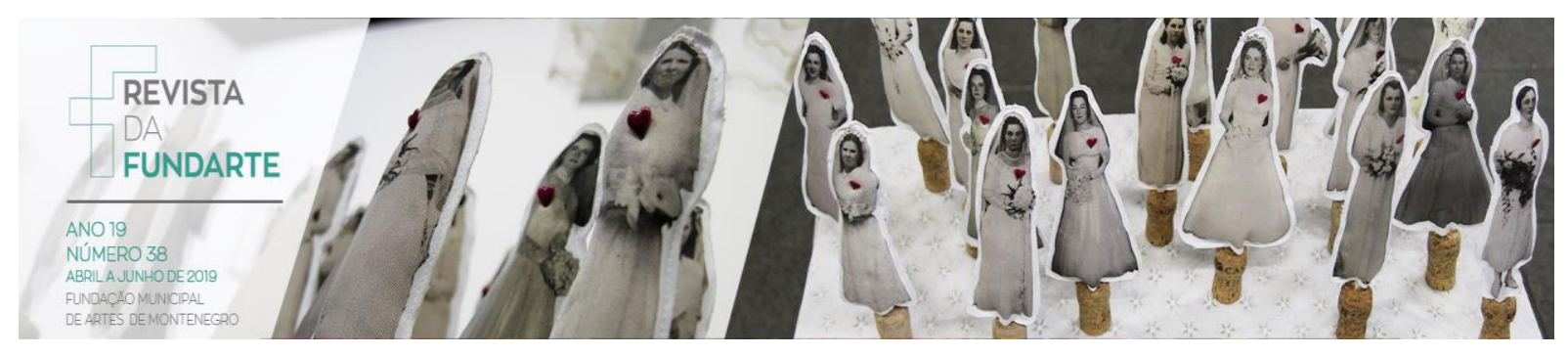

demonstra conhecimento dos alunos sobre princípios contrapontísticos, os quais se enquadram na categoria conhecimentos e habilidades musicais (BALLANTYNE, 2005; 2006). Harmonicamente, a variação inicia na dominante (Ré Maiơxi) e não na tônica.

Figura 5 - Variações com emprego de notas da segunda oitava
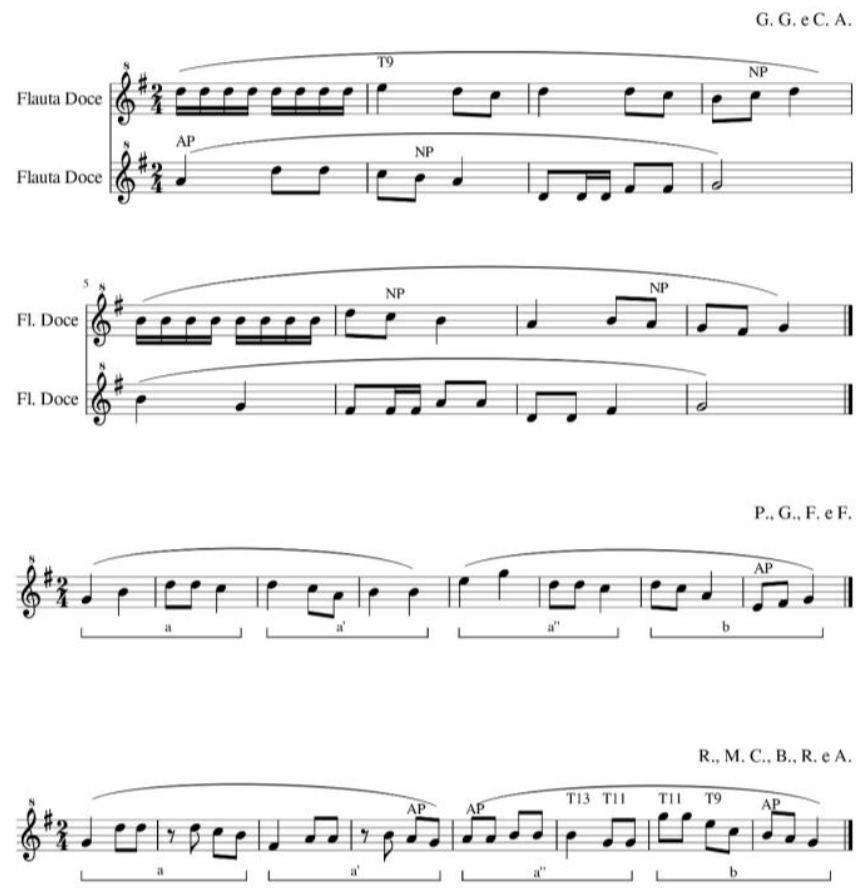

A segunda variação da Figura 5 evidencia contornos melódicos semelhantes, embora a extensão da segunda frase abranja um intervalo de décima. Curioso notar que há compassos idênticos no meio das duas frases (compassos 2,3 e 5,6). No terceiro exemplo, há um salto de oitava na segunda frase e a extensão do trecho abrange um intervalo de nona. Esse mesmo exemplo não segue a harmonia sugerida pelo tema, principalmente nos últimos três compassos e a análise aponta tais notas como notas de tensão (T13, T11 e T9) na partitura. Poder-se-ia especular que a equipe rearmonizou a última frase (Em, G, C, D G ao invés de Em, D, D7 G, $D^{7}$

TORRES, Maria Cecilia de Araujo Rodrigues; WEICHSELBAUM, Anete Susana. Formação de professores no curso de licenciatura em música: Uma experiência com a prática instrumental e composicional com a flauta-doce. Revista da FUNDARTE, Montenegro, p.164-189, ano 19, no 38, abril/junho de 2019.

Disponível em: http://.seer.fundarte.rs.gov.br/index.php/RevistadaFundarte/index> 28 de junho de 2019 


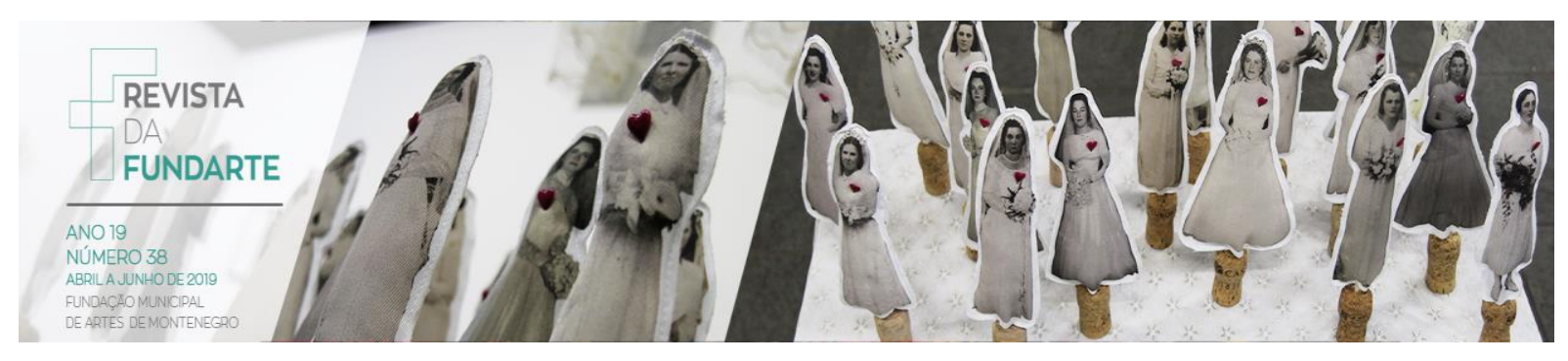

G), o que sugere relação com a categoria conhecimento e habilidade musical (BALLANTYNE, 2005; 2006).

Em relação aos aspectos harmônicos, foi observado que, com exceção de uma, as dezenove variações se mantiveram na tonalidade estipulada, terminando na tônica, porém duas não seguem a harmonia fornecida pela cifragem (Ver Fig. 5, a terceira composição, como mencionado anteriormente e Fig. 6 cuja composição apresenta uso de notas cromáticas).

Em algumas melodias, observou-se o uso de inflexões como notas de passagens e apogiaturas. Contudo, observa-se que tal assunto não foi estudado nas disciplinas do curso até o segundo semestre.

A maioria dos inícios das frases foi construída com a nota Sol ${ }^{3}$ ou Ré $^{4}$, como no modelo do Tema apresentado a duas vozes. Uma das variações (Figura 6) utilizou notas cromáticas, que foram as posições estudadas de Sol $\#^{3}$ e Ré \# $\#^{3}$ em outros repertórios. O desenho melódico com movimento cromático na primeira frase ficou levemente interrompido por causa da pausa, porém, na segunda frase ficou configurado, contudo, tal cromatismo não observa a harmonia estabelecida introduzindo notas de tensão como Sol \# no segundo e sétimo compasso no acorde de Ré maior com sétima.

Figura 6 - Variação com notas cromáticas

R. eJ.C..

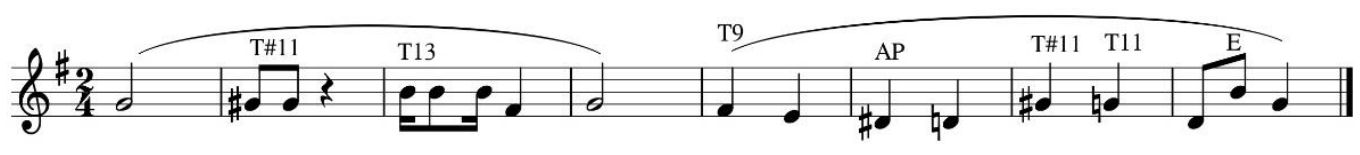

É inquestionável que a prática da realização da variação apresente alto potencial artístico e técnico, contudo, ela também pode ser utilizada pelos professores para atender finalidades pedagógicas, como exercício da prática

TORRES, Maria Cecilia de Araujo Rodrigues; WEICHSELBAUM, Anete Susana. Formação de professores no curso de licenciatura em música: Uma experiência com a prática instrumental e composicional com a flauta-doce. Revista da FUNDARTE, Montenegro, p.164-189, ano 19, ㄲo 38 , abril/junho de 2019.

Disponível em: http://.seer.fundarte.rs.gov.br/index.php/RevistadaFundarte/index> 28 de junho de 2019 


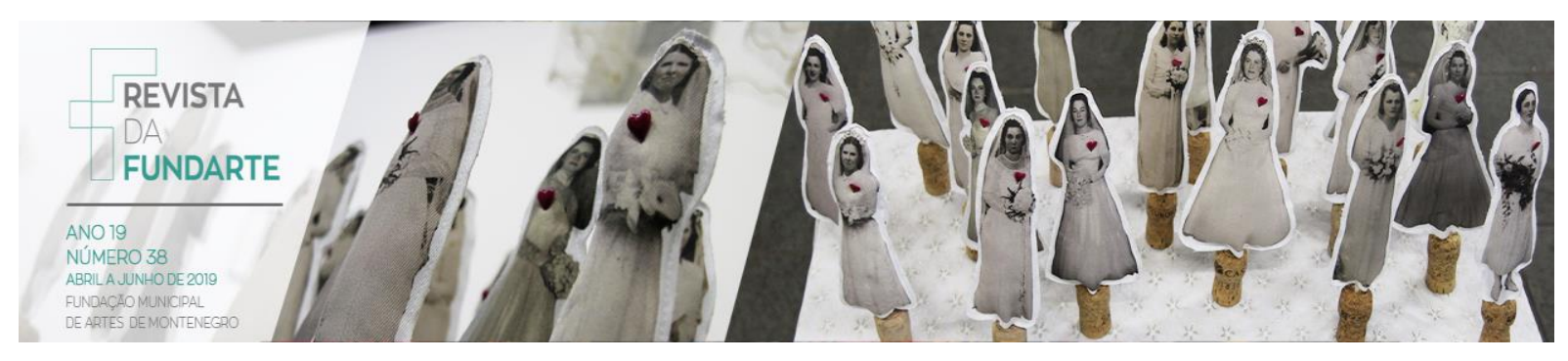

instrumental e a oportunidade de realizar composição musical com critérios definidos. Para Brins et al (1979), que aborda variações e improvisações ao teclado, cada variação deve se basear em, ao menos, uma técnica específica de elaboração (p. 126). O pianista iniciante pode realizar exercícios arpejando acordes, realizando passagens diatônicas com notas de passagens entre as notas da melodia, bem como, do baixo, e ainda acrescentando passagens cromáticas intercaladas às notas de passagem da melodia.

Almada (2000) apresenta algumas considerações sobre variação melódica, considerando algumas técnicas no "trato dos estilos populares" (p. 244), tais como variação intervalar, rítmica, ornamentação, também conhecida como embelezamento melódico, interpolação de notas dos acordes (acréscimo de notas formando a assim chamada moldura harmônica) e combinação de motivos.

No contexto da prática musical de conjuntos vocais ou instrumentais em escolas, como bandas, a educadora musical Campbell (1991, p. 268-271) sugere a realização de atividades de variações sobre um tema durante a execução musical. Em sua proposta, a autora não aborda a escrita de variações pelos alunos, mas focaliza o desenvolvimento de habilidades aurais, da memorização e da improvisação. A autora considera importante que os alunos possam inicialmente executar com competência melodias em uníssono, privilegiando aspectos da percepção e da execução. Ela parte da realização de melodias conhecidas ou daquelas que estão sendo estudadas e sugere que o professor forneça instruções claras para a variação de um dos elementos de cada vez, como mudar o tom da melodia para seu homônimo, transformá-la em melodia modal, bem como mudar a fórmula de compasso. Segundo Campbell, se os alunos seguem tais parâmetros, não há como as respostas musicais serem consideradas inadequadas. Ela ainda acrescenta que é necessário discutir os efeitos do uso dos recursos como "notas de

TORRES, Maria Cecilia de Araujo Rodrigues; WEICHSELBAUM, Anete Susana. Formação de professores no curso de licenciatura em música: Uma experiência com a prática instrumental e composicional com a flauta-doce. Revista da FUNDARTE, Montenegro, p.164-189, ano 19, № 38, abril/junho de 2019.

Disponível em: http://.seer.fundarte.rs.gov.br/index.php/RevistadaFundarte/index> 28 de junho de 2019 


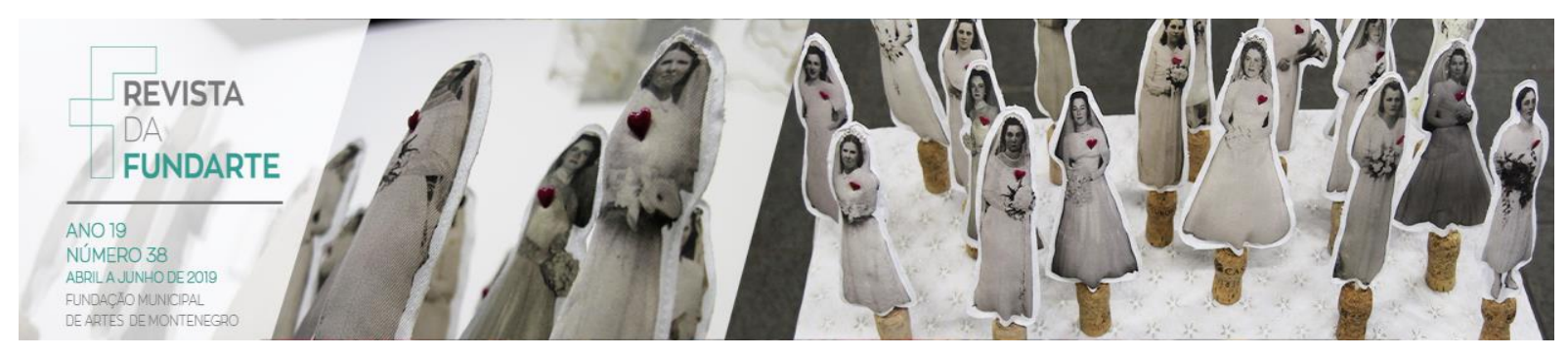

passagens, bordaduras superiores e inferiores, mordentes, suspensões, antecipações e síncopes" (p. 271) xii nas execuções dos alunos.

\section{Discussão e contribuições}

Discussão: conhecimentos e habilidades instrumentais na formação dos licenciandos

A maioria das variações compostas pelos licenciandos atendeu à tarefa proposta, sendo que os dados permitiram analisar as composições de acordo com os elementos composicionais empregados, conforme os elementos de execução no instrumento e de acordo com as categorias analíticas propostas no início do texto.

\subsection{Elementos composicionais}

Considerando os exemplos apresentados, pode-se resumir que os procedimentos de variação mais utilizados foram (a) a variação intervalar/melódica, na qual os estudantes substituíam notas à melodia dada ou acrescentavam notas de passagens, apogiaturas com ritmos utilizados no tema ou com ritmos variados, e (b) a variação rítmica, que mantinha muita semelhança com uma das frases fornecidas do tema. Considerando os critérios estipulados (unidade rítmica e/ou melódica, segmentação, extensão e manutenção da harmonia implícita), das vinte variações compostas, cinco apresentavam grande unidade rítmico-melódica, mantendo o mesmo grupo de ritmos nas frases/semifrases, bem como algumas variações utilizavam sequências com ritmos sincopados e/ou contratempos, porém, outras não apresentavam unidade intervalar, caracterizando frases com contornos mais livres. Em relação à extensão, a maioria das variações utilizava a mesma extensão do tema (dentro da oitava), três utilizavam notas da segunda oitava, como o $\mathrm{Mi}^{4}$ e o Sol${ }^{4}$

TORRES, Maria Cecilia de Araujo Rodrigues; WEICHSELBAUM, Anete Susana. Formação de professores no curso de licenciatura em música: Uma experiência com a prática instrumental e composicional com a flauta-doce. Revista da FUNDARTE, Montenegro, p.164-189, ano 19, № 38, abril/junho de 2019.

Disponível em: http://.seer.fundarte.rs.gov.br/index.php/RevistadaFundarte/index> 28 de junho de 2019 


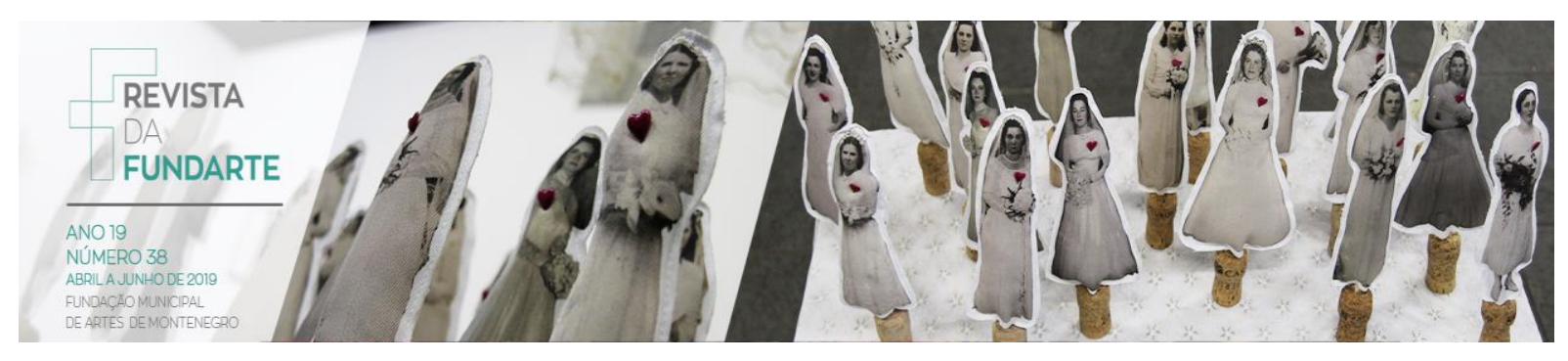

e uma utilizava notas não diatônicas, como o Ré $\#^{3}$ e o Sol $\#^{3}$. Em relação à segmentação das frases, muitas seguiam o mesmo padrão do Tema proposto, com segmentação de quatro compassos por frase e dois por semifrase, porém outras apresentavam frases irregulares.

Por fim, quanto aos aspectos harmônicos, as composições mantiveram-se na tonalidade original, porém uma delas iniciou pela dominante, outra usou harmonização diferente na segunda frase e uma terceira utilizou notas cromáticas que descaracterizaram a harmonia implícita do Tema, introduzindo notas de tensões harmônicas nas duas últimas composições citadas.

\subsection{Elementos da execução da flauta-doce}

Em relação à execução na flauta doce, dois aspectos podem ser pontuados a partir das tarefas desenvolvidas: a segmentação e a extensão de posições (notas) empregada. A segmentação pode revelar clareza e compreensão estrutural dos licenciandos na divisão em frases, a qual tem efeito direto na execução do instrumento considerando a respiração. As primeiras variações seguiam essa coerência estrutural, mantendo semelhança com a peça composta (Dueto: Tema e Variações) e seguindo o mesmo padrão. Algumas composições apresentaram divisão irregular de frases, e, nesse caso, as respirações não coincidiram com uma das vozes do Tema original.

Nesse sentido, considera-se muito válido abordar com os estudantes conhecimentos desenvolvidos e adquiridos em outras disciplinas, como, nesse caso, em disciplinas como Análise (Morfologia) ou Arranjo na prática instrumental e na realização de tarefas composicionais. Segundo Mattos (2006), que se apoia na literatura da área de Análise, a pessoa que analisa uma obra deve perceber claramente os elementos fraseológicos, incluindo os incisos, membros de frases,

TORRES, Maria Cecilia de Araujo Rodrigues; WEICHSELBAUM, Anete Susana. Formação de professores no curso de licenciatura em música: Uma experiência com a prática instrumental e composicional com a flauta-doce. Revista da FUNDARTE, Montenegro, p.164-189, ano 19, № 38, abril/junho de 2019.

Disponível em: http://.seer.fundarte.rs.gov.br/index.php/RevistadaFundarte/index> 28 de junho de 2019 


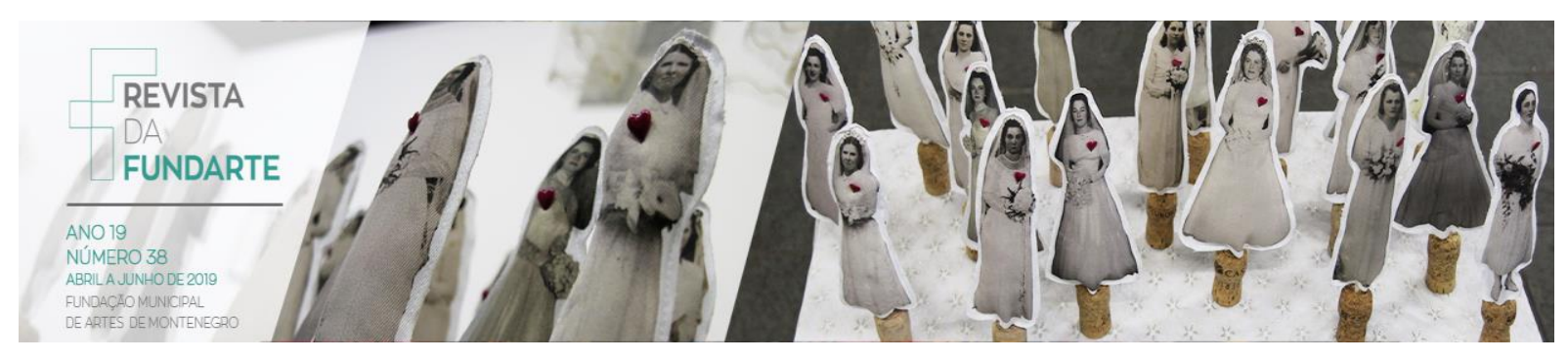

frases e períodos, a fim de realizar a segmentação melódica. O mesmo autor ainda pontua que a subdivisão de elementos menores como incisos em uma obra constitui-se em uma tarefa mais sutil do que identificar seções maiores formadas por períodos, frases. Considerando que tal aspecto está relacionado à categoria conhecimentos e habilidades musicais proposta por Ballantyne $(2015$; 2016), é possível sugerir ao professor que aponte tais situações quando estas ocorrem nas tarefas desenvolvidas, pois alguns conhecimentos e habilidades serão desenvolvidos e aperfeiçoados em outras disciplinas durante sua formação.

O segundo aspecto relacionado à execução trata da extensão utilizada pelos estudantes, que, no caso da flauta doce, depende da aprendizagem de digitações ou posições para as notas, e assim sugere quais são as opções e os limites técnicos para a composição que deverá ser executada pelo(s) próprio(s) estudante(s). A variação 1 , cuja extensão ficou delimitada pelo intervalo de sexta, apresentou muita coerência com o motivo a (semifrase), bem como as demais contidas no intervalo de oitava, que prevaleceram. As variações que utilizaram notas mais agudax ${ }^{\text {xiii, }}$ como $\mathrm{Mi}^{4}$ e Sol${ }^{4}$ também apresentaram contornos adequados na extensão da décima. $\mathrm{A}$ audição das variações da Figura 5 permitiu estabelecer que os estudantes executam tais posições com certo grau de fluência e técnica adequada, o que amplia o leque de posições a serem utilizadas.

Convém mencionar que conhecimentos oriundos de disciplinas como Harmonia, Arranjo e Improvisação e Composição ainda não foram trabalhados nesta etapa do curso com os alunos que desenvolveram suas variações, porém os resultados podem ser considerados muito satisfatórios, considerando as produções apresentadas. Outro aspecto é considerar que as composições feitas em grupo também oportunizam aos estudantes a socialização de conhecimentos já adquiridos a partir de suas experiências musicais.

TORRES, Maria Cecilia de Araujo Rodrigues; WEICHSELBAUM, Anete Susana. Formação de professores no curso de licenciatura em música: Uma experiência com a prática instrumental e composicional com a flauta-doce. Revista da FUNDARTE, Montenegro, p.164-189, ano 19, № 38, abril/junho de 2019.

Disponível em: http://.seer.fundarte.rs.gov.br/index.php/RevistadaFundarte/index> 28 de junho de 2019 


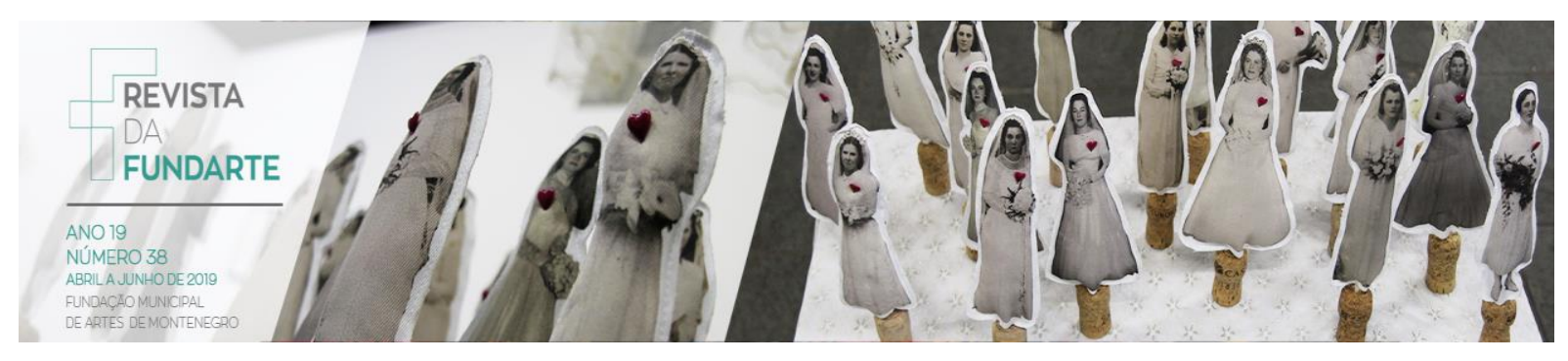

\subsection{Contribuições e desdobramentos}

Em relação à questão colocada no início do texto: quais são os conhecimentos e habilidades musicais e instrumentais a serem trabalhados com os licenciandos na disciplina e durante sua formação, considerando-se a presente disciplina, salienta-se a importância de desenvolver o conhecimento e habilidade musical (BALLANTYNE, 2005; 2006) voltada ao repertório de estudo do estudante e em atividades de composição instrumental, bem como o conhecimento do conteúdo da matéria (SHULMAN, 1986), também entendido como conhecimento e habilidade do conteúdo (WEICHSELBAUM, 2013) no ensino do instrumento.

Em relação ao curso, é importante que tais conhecimentos e habilidades estejam articulados entre as diversas disciplinas, a fim de que se promova uma abordagem interdisciplinar e também um esforço de transferência de conhecimentos e habilidades, embora, sabe-se que nem sempre a transferência seja generalizável entre diferentes áreas ou domínios (SHULMAN, SPARKS, 1992; COWELL, 2011).

A segmentação mostrou-se um critério que pode ser melhor explorado pelos professores e estudantes nas aulas e diz respeito a conhecimentos gerados em disciplinas como Análise, Harmonia, e assim relaciona-se à categoria de conhecimentos e habilidades musicais propostas por Ballantyne (2005; 2006). Alguns estudantes não estavam cientes da importância de realizar o fraseado conforme o exemplo fornecido (duas semifrases), fator este evidenciado na execução musical (respiração).

Observou-se que a extensão utilizada pelos estudantes foi o aspecto que mais variou dentre as tarefas, o qual sofre influência da aprendizagem e do estudo individual das posições na flauta doce pelos licenciandos na presente disciplina. Esta categoria tem a ver com os conhecimentos do conteúdo da matéria

TORRES, Maria Cecilia de Araujo Rodrigues; WEICHSELBAUM, Anete Susana. Formação de professores no curso de licenciatura em música: Uma experiência com a prática instrumental e composicional com a flauta-doce. Revista da FUNDARTE, Montenegro, p.164-189, ano 19, № 38, abril/junho de 2019.

Disponível em: http://.seer.fundarte.rs.gov.br/index.php/RevistadaFundarte/index> 28 de junho de 2019 


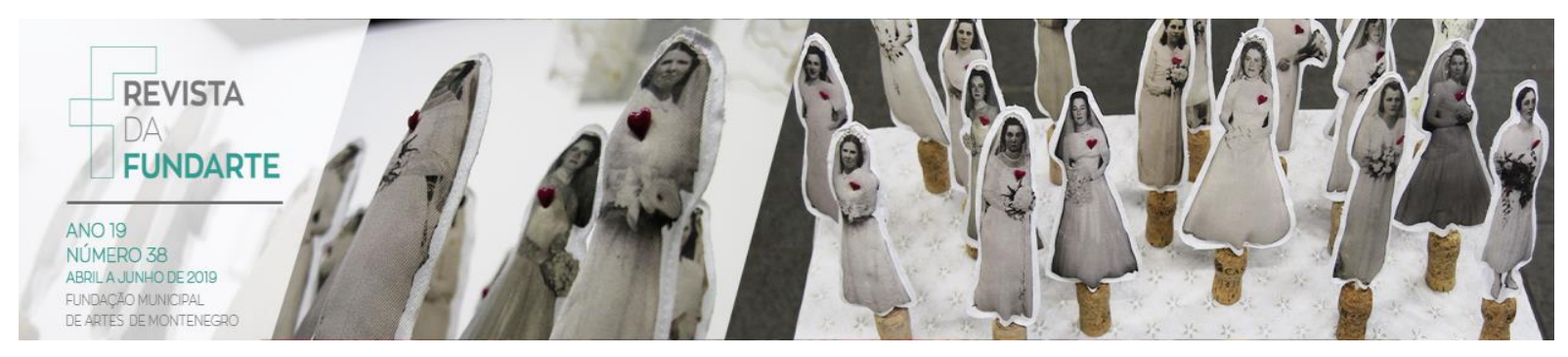

(SHULMAN, 1986) e conhecimentos e habilidades do conteúdo (WEICHSELBAUM, 2013) construídos pelos estudantes durante o semestre.

Por fim, outro aspecto a ser ressaltado é o estímulo ao exercício da composição na aula da prática instrumental. Mesmo a tarefa sendo limitada, a prática de escrever variações e executá-las pareceu ser bem acessível e prazeroso aos estudantes, demandando-Ihes diversos conhecimentos e habilidades musicais, como ser capaz de escrever na pauta a melodia e ritmo que tocavam, apreciar, avaliar e, em algumas situações, fazer ajustes na variação e comparar o resultado sonoro da voz composta com a outra voz proposta ou mesmo com o acompanhamento do piano, que aconteceu em algumas das variações a partir da proposição dos alunos.

A proposta de tocar variações compostas em aula configurou-se como uma atividade muito rica em termos de apreciação por parte dos colegas e também no que tange à escrita musical, pois alguns alunos tiveram dificuldades em escrever exatamente o que estavam executando no instrumento e também em relação à execução e fluência na flauta doce com a inserção de notas agudas ou de contratempos, pois tivemos a ampliação de três variações (originais do Método) para mais de 20 variações criadas pelos alunos dos dois semestres.

A pesquisa de Ballantyne (2005) mostrou que os professores em início de carreira valorizaram muito o aprendizado de conhecimentos e habilidades musicais desenvolvidos na graduação, visando o ensino de música na escola. A autora apontou que os licenciados queriam se sentir mais seguros e confiantes, mencionaram que sentiram a falta de um maior aprofundamento nos conhecimentos e habilidades desenvolvidos em disciplinas curriculares da área da música ao se defrontarem com as demandas da profissão.

Um dos aspectos que destacamos foi de que, embora os alunos ainda não tivessem cursado as disciplinas de Harmonia, Arranjo e Improvisação e

TORRES, Maria Cecilia de Araujo Rodrigues; WEICHSELBAUM, Anete Susana. Formação de professores no curso de licenciatura em música: Uma experiência com a prática instrumental e composicional com a flauta-doce. Revista da FUNDARTE, Montenegro, p.164-189, ano 19, № 38, abril/junho de 2019.

Disponível em: http://.seer.fundarte.rs.gov.br/index.php/RevistadaFundarte/index> 28 de junho de 2019 


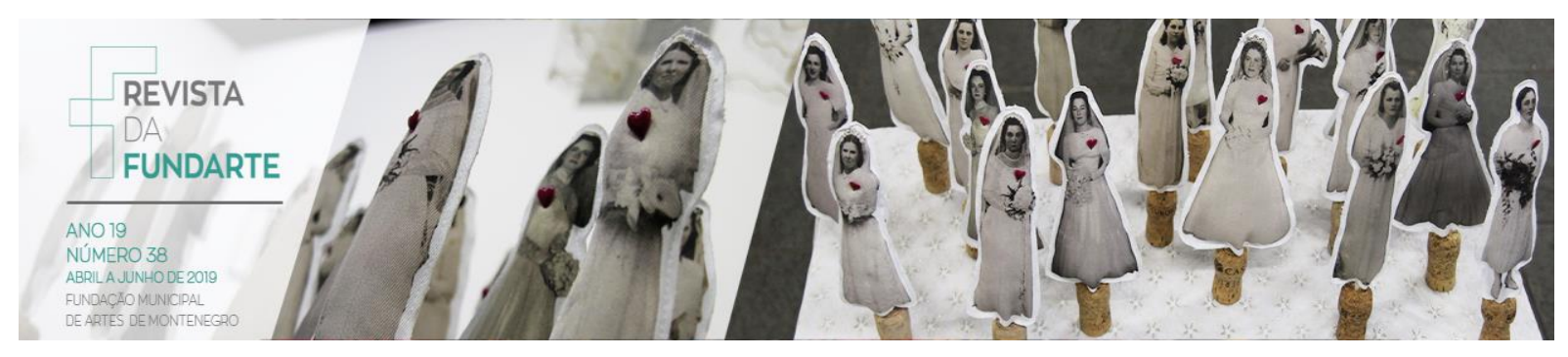

Composição, pois essas acontecem em outros semestres posteriores do Curso, pelo resultado e análise das composições, pudemos ressaltar que eles tiveram subsídios para realizar a tarefa, dentro de limites e saberes musicais de cada dupla ou trio.

Finalizamos essas reflexões compartilhando com outros colegas educadores musicais que atuam em cursos de licenciaturas com práticas de flauta doce em grupos, ou de outros instrumentos, o quanto essa atividade foi instigante e desafiadora não só para os nossos alunos visando trabalhar conhecimentos e habilidades do conteúdo da disciplina, mas também para nós professoras, no sentido de ampliarmos os nossos fazeres musicais em sala de aula em termos de criação musical coletiva, de trabalharmos com diferentes propostas para a flauta doce no contexto do Ensino Superior, inclusive com o propósito de exercitarmos a escrita e análise de partituras e promover atividades composicionais.

\section{Referências:}

ALMADA, Carlos. Arranjo. Campinas: Editora da Unicamp, 2000.

BALLANTYNE, Julie. Effectiveness of preservice music teacher programs: Perceptions of early-career music teachers. $263 \mathrm{f}$. Thesys (Doctor of Philosophy). Centre for Innovation in Education, Queensland, Australia, 2005. Disponível em: <http://eprints.qut.edu.au/16074/1/Julie_Ballantyne_Thesis.pdf>. Acesso em $13 / 12 / 2011$.

BALLANTYNE, Julie. Reconceptualising Preservice Teacher Education Courses for Music Teachers: The Importance of Pedagogical Content Knowledge and Skills and Professional Knowledge and Skills. In: Research Studies in Music Education, Number 26, 2006, p. 37-50.

BENNETT, Roy. Forma e Estrutura na Música. Tradução de Luiz Carlos Csëko, revisão técnica Luiz Paulo Horta. Rio de Janeiro: Jorge Zahar Ed., 1986.

BRINGS, Allen; BURKHART, Charles; KAMIEN, Roger; KRAFT, Leo; PERSHING, Drora. Improvisation. In: A new approach to keyboard Harmony. New York: W.W. Norton \& Company, Inc., 1979, p. 116- 130.

TORRES, Maria Cecilia de Araujo Rodrigues; WEICHSELBAUM, Anete Susana. Formação de professores no curso de licenciatura em música: Uma experiência com a prática instrumental e composicional com a flauta-doce. Revista da FUNDARTE, Montenegro, p.164-189, ano 19, no 38, abril/junho de 2019.

Disponível em: http://.seer.fundarte.rs.gov.br/index.php/RevistadaFundarte/index> 28 de junho de 2019 


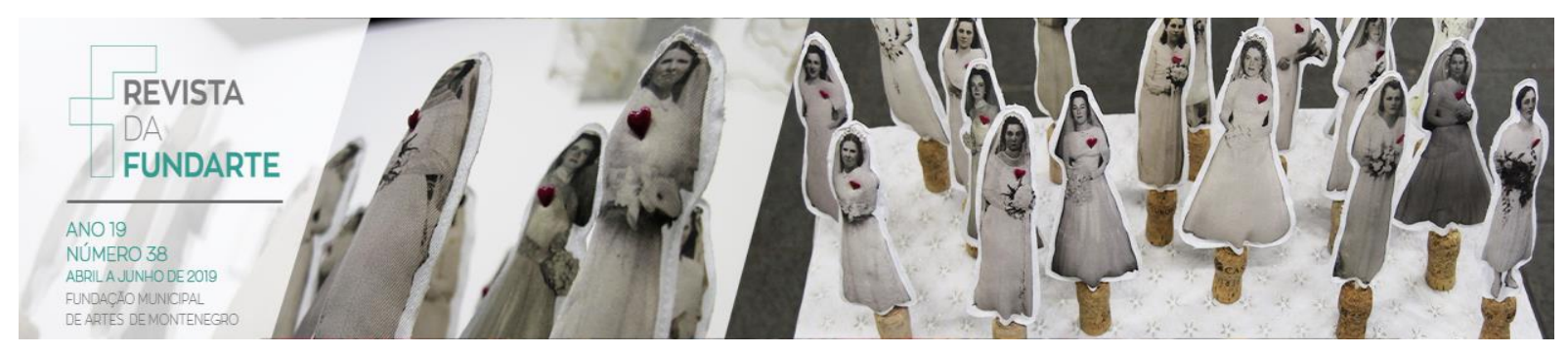

CAMPBELL, Patricia Shehan. Music Learning in the Ensemble Setting. In: Lessons from the world. A Cross-cultural Guide to Music Teaching and Learning. New York: Schirmer Books, 1991, p. 245-275.

COLWELL, Richard. Reflections on music teacher education. In: Action, Criticism, and Theory for Music Education, volume 10, n. 2, 2011, p. 127-160. Disponível em $<$ http.://act.maydaygroup.org/articles/Colwell10_2.pdf>. Acesso em 20 de dezembro de 2011

CONWAY, Colleen Marie; HODGMAN, Thomas. Teaching music in higher education. New York: Oxford University Press, 2009.

FREIXEDAS, Cláudia Maradei. Caminhos criativos no ensino de flauta doce. $151 \mathrm{f}$. Dissertação (Mestrado) - Programa de Pós-Graduação em Música, Escola de Comunicações e Artes, Universidade de São Paulo, São Paulo, 2015.

LIRA, IIma. Rumo a um novo papel da flauta doce na educação musical brasileira. Dissertação (Mestrado em Educação Musical). York, Universidade de York, 1984.

MATTOS, Fernando Lewis de. Análise Musical I [ART 03163] - Apostila. Porto Alegre, agosto de 2006. Disponível em: <http://hugoribeiro.com.br/bibliotecadigital/Matos-Apostila_Analise_1.pdf $>$. Acesso em 20/10/2018.

PAOLIELLO, Noara de Oliveira. A flauta doce e sua dupla função como instrumento artístico e de iniciação musical. 43 f. Monografia (Graduação: Licenciatura Plena em Educação Artística - Habilitação em Música) - Centro de Letras e Artes - Instituto Villa-Lobos, Universidade Federal do Rio de Janeiro, Rio de Janeiro, 2007.

SHULMAN, Lee S. Those who understand: knowledge growth in teaching. Educational Researcher, American Educational Research Association (AERA), Feb. 1986 , v. 15 , n. 2, p. 4-14.

SHULMAN, Lee; SPARKS, D. Merging Content Knowledge and Pedagogy: An interview with Lee Shulman. Jornal of Staff Development, 13 (1), 14-16.

TRINDADE, Brasilena Pinto. O ensino-aprendizagem da disciplina Flauta Doce em Grupo I no Curso de Licenciatura em Música da Faculdade Evangélica de Salvador. In: XVI Encontro Anual da ABEM e VI Congresso Regional da ISME na América Latina, 8 a 11 de outubro de 2007, Campo Grande. Anais... Editora da Universidade Federal de Mato Grosso do Sul (UFMS), 2007, não paginado.

TORRES, Maria Cecilia de Araujo Rodrigues; WEICHSELBAUM, Anete Susana. Formação de professores no curso de licenciatura em música: Uma experiência com a prática instrumental e composicional com a flauta-doce. Revista da FUNDARTE, Montenegro, p.164-189, ano 19, no 38, abril/junho de 2019.

Disponível em: http://.seer.fundarte.rs.gov.br/index.php/RevistadaFundarte/index> 28 de junho de 2019 


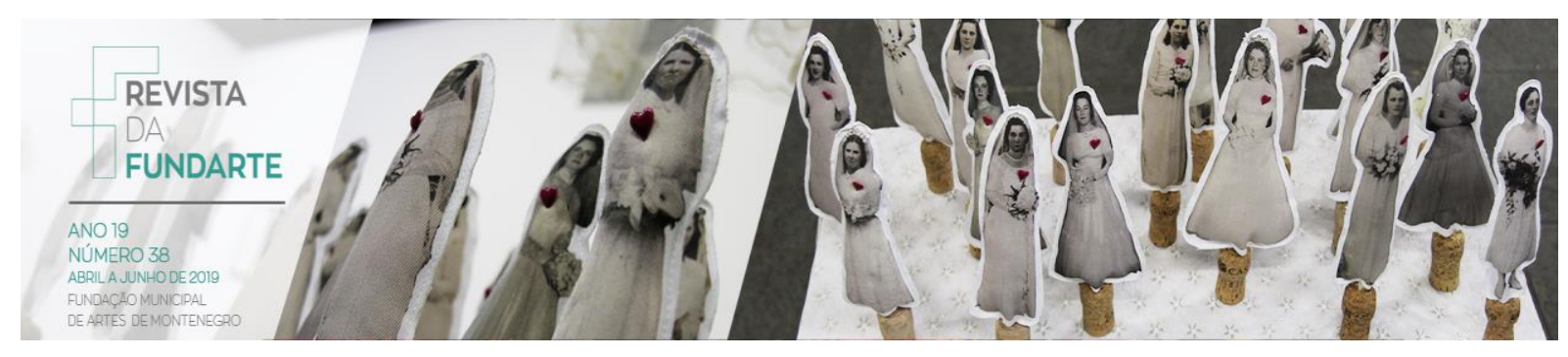

WEICHSELBAUM, Anete Susana. Flauta doce em um curso de licenciatura em música: entre as demandas da prática musical e das propostas pedagógicas do instrumento voltadas ao Ensino Básico. Tese (Doutorado em Música) - Instituto de Artes, Programa de Pós-Graduação em Música, Universidade Federal do Rio Grande do Sul, 2013.

WEILAND, Renate; SASSE, Ângela; WEICHSELBAUM, Anete. Sonoridades Brasileiras: método para flauta doce soprano. Curitiba: DeArtes, 2009.

i Agradecemos à Professora Dra. Jusamara Souza pela leitura cuidadosa do artigo e pelas sugestões. Agradecemos e dedicamos este trabalho aos alunos da disciplina de "Flauta doce no contexto escolar".

ii Há traduções semelhantes para o português: conhecimento da matéria ensinada (subject knowledge matter), adotada por Borges (2001) e conhecimento da matéria do conteúdo, segundo Azevedo

(2007). Para maiores informações, consultar:

AZEVEDO, Maria Cristina de Carvalho Cascell de. Os saberes docentes na ação pedagógica dos estagiários de música: dois estudos de caso. 448f. Tese (Doutorado em Música) - Programa de PósGraduação em Música, Instituto de Artes, Universidade Federal do Rio Grande do Sul, Porto Alegre, 2007.

BORGES, Cecília. Saberes docentes: diferentes tipologias e classificações de um campo de pesquisa. Educação e Sociedade. Campinas, CEDES, vol.22, n.74, p. 59-76, 2001. Disponível em: $<$ http://www.scielo.br/scielo.php?script=sci_pdf\&pid=S0101 -

$73302001000100005 \&$ lng =en\&nrm=iso\&tlng=pt>. Acesso em 02/08/2012.

iii A sigla PCK (Pedagogical Content Knowledge) é utilizada por Conway e Hodgman (2009) em publicação que se refere à docência em música.

iv "This category includes such areas as performance skills, conducting skills, aural perception skills, composition skills and music history knowledge" (BALLANTYNE, 2006, p. 45).

$\checkmark$ "[...] the knowledge of learners and their characteristics [...], ability to organise the learning environment, and the ability to utilise various instructional strategies" (BALLANTYNE, 2006, p. 44).

vi "[...] knowledge of music teaching techniques, [...], assessing students' abilities in the various aspects of music, and explaining and demonstrating musical concepts". (BALLANTYNE, 2006, p. 41).

vii Todas as variações estão identificadas com as iniciais dos nomes dos alunos.

viii Por exemplo, nessa etapa do curso, não foi considerada para a análise um estudo mais detalhado de técnicas aplicadas ao embelezamento melódico, como o uso de antecipações, suspensões, mas procurou-se observar o uso de apogiaturas (AP), notas de passagem (NP) e notas de tensão (por exemplo T9, T13) que podem ser admitidas à harmonia implícita. Estes aspectos foram considerados em relação à sua pertinência harmônica considerando-se o Dueto original.

ix No presente texto, as indicações de numeração da escala geral ao lado da nota, por exemplo Lá3, $\mathrm{Sol}^{4}$, referem-se ao sistema brasileiro. É importante salientar que a flauta doce soprano sempre soa uma oitava acima de sua escrita e o número 8 é indicado acima da clave de sol.

x Neste texto, as expressões membro de frase e semifrase são utilizadas como sinônimos.

xi Nota Lá ${ }^{3}$ indicada como AP - apogiatura - na partitura.

TORRES, Maria Cecilia de Araujo Rodrigues; WEICHSELBAUM, Anete Susana. Formação de professores no curso de licenciatura em música: Uma experiência com a prática instrumental e composicional com a flauta-doce. Revista da FUNDARTE, Montenegro, p.164-189, ano 19, no 38, abril/junho de 2019.

Disponível em: http://.seer.fundarte.rs.gov.br/index.php/RevistadaFundarte/index> 28 de junho de 2019 


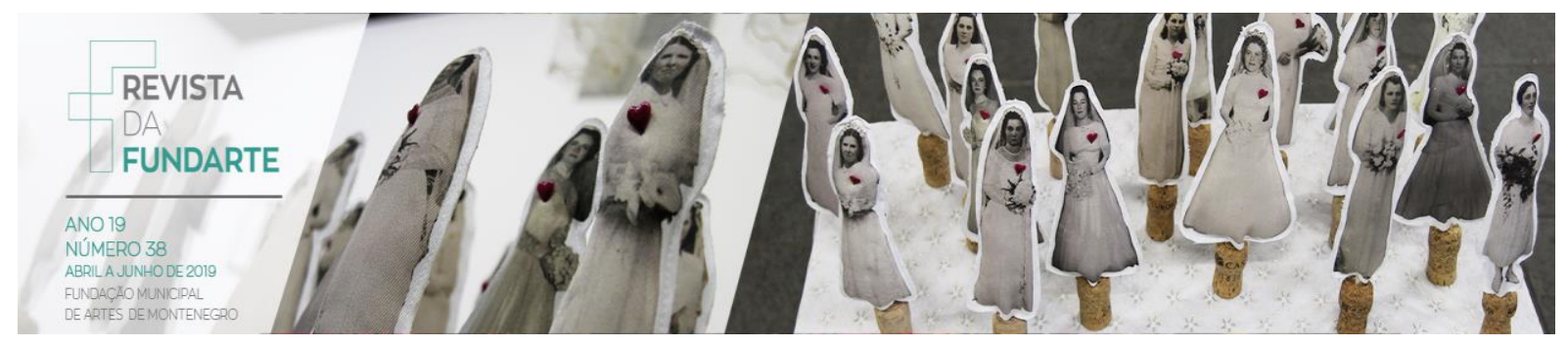

xii "[...] such as passing tones, upper and lower neighbors, turns and trills, suspensions, anticipations, and syncopations." (CAMPBELL, p. 271).

xiii Como já mencionado antes, as notas mais agudas escritas na pauta como $\mathrm{Mi}^{4}$, Sol${ }^{4}$, soam oitava acima, considerando que a flauta doce soprano soa uma oitava acima da escrita.

TORRES, Maria Cecilia de Araujo Rodrigues; WEICHSELBAUM, Anete Susana. Formação de professores no curso de licenciatura em música: Uma experiência com a prática instrumental e composicional com a flauta-doce. Revista da FUNDARTE, Montenegro, p.164-189, ano 19, no 38, abril/junho de 2019.

Disponível em: http://.seer.fundarte.rs.gov.br/index.php/RevistadaFundarte/index> 28 de junho de 2019 